\title{
ÇALIŞMA ORTAMI ÖZELLİKLERİNİN İŞE YABANCILAŞMAYA ETKİLERİ: BİLGİ TEKNOLOJİSİ ÇALIŞANLARI ÜZERİNE BİR
}

\author{
ARAŞTIRMA ${ }^{1}$ \\ Senem NART 2 \\ Received Date (Başvuru Tarihi): \\ $31 / 03 / 2020$ \\ Cemal ÇELIK 3 \\ Accepted Date (Kabul Tarihi): \\ $20 / 05 / 2020$ \\ Sima NART 4 \\ Published Date (Yayın Tarihi): \\ $25 / 06 / 2020$
}

Calıșmada ilk yazar Sorumlu Yazar (Corresponding Author) rolündedir.

$\ddot{O Z Z}$

Anahtar Kelimeler:

İşe Yabanculaşma

$\dot{I}_{\text {Ş Özerkliği }}$

Rol Çatışması

İş Talep-Kaynak Modeli

JEL Kodlari:

M150, M120, M110
İçinde bulunduğumuz Bilgi Çağında, Bilgi Teknolojileri (BT) çalışanları, yeni ekonominin büyümesinde en kritik faktördür. Bu nedenle iş ortamında BT çalı̧anlarının iş ortamlarının doğasının anlaşılması önemli bir araştırma alanı olarak görülmektedir. Böylelikle çalışmanın amacı, iş ortamını oluşturan; iş özerkliği, rol çatışması ve örgütsel adalet değiş̧enlerinin $B T$ çalışanlarının işe yabancılaşma algılarn üzerindeki doğrudan ve dolaylı etkilerini incelemektir. Bu amaç doğrultusunda İstanbul'da yer alan yedi teknoloji şirketinin çalışanlarından online olarak tasarlanan bir anket aracilığı ile gerekli veriler toplanmıştır. 172 sektör çalışanın katılımı ile elde edilen veriler, yapısal denklem modeli ile analiz edilmiştir. Araştırma sonucunda değişkenler arasında doğrudan ve dolaylı ilişkiler tespit edilmiştir.

$\begin{array}{lllll}\text { Keywords: } & \text { Job Alienation } & \text { Autonomy } & \text { Role Conflict } & \begin{array}{c}\text { Job Demands-Resources } \\ \text { Model }\end{array} \\ \text { JEL Codes: } & \text { M150 } & \text { M120 } & \text { M110 }\end{array}$

\footnotetext{
${ }^{1}$ Bu makale, 6-9 Kasım 2018 tarihleri arasında Atina' da düzenlenen “9. International Conference on Political Economy” adlı etkinlikte sözlü bildiri olarak sunulan ve özeti, kongre bildiri kitabında genişletilmiş özet şeklinde basılmış olan, "The Antecedents of Work Alienation: Implications For Information Technology Employees" başlıklı bildirinin genişletilmiş halidir

${ }^{2}$ Dr. Öğr.Üyesi, Bandırma Onyedi Eylül Üniversitesi, U.B.F., snart@bandirma.edu.tr, $\quad$ https://orcid.org/0000-0001-9675-5229

${ }^{3}$ Öğr. Gör., Bandırma Onyedi Eylül Üniversitesi, ccelik@bandirma.edu.tr,

${ }^{4}$ Prof. Dr., Sakarya Üniversitesi, İşletme Fakültesi, snart@sakarya.edu.tr, https://orcid.org/0000-0002-4027-3789 https:// orcid.org/0000-0002-8264-9828
} 


\section{EXTENDED ABSTRACT}

\section{EFFECTS OF WORKPLACE ENVIRONMENT CHARACTERISTICS ON JOB ALIENATION: A RESEARCH ON INFORMATION TECHNOLOGY EMPLOYEES}

\section{LITERATURE}

The information technology sector is considered as the new driving force of an economy and is therefore defined as the "strategic sector". The most important asset of the sector which has such critical importance is the information technology employees who are educated and qualified human resources. On the other hand, as in many other sectors, employees in this sector may also face a psychosocial risk due to non-corporate practices. This traditional system can cause disappointment to employees and subsequently to alienate against their jobs. In this context, one of the most important issues ignored in the information technology sector is determining the reasons underlying the negative attitudes of the employees towards their works. The "Job Demands - Resources Model", which was developed by Demerouti et al. (2001), which aims to explain the factors necessary for the productivity and well-being of the employees in the workplace environment, provides an explanatory perspective. Work alienation arises as a result of various job demands that the employee perceives as obstacles. According to the Job Demands - Resources model, this situation may lead to emotional exhaustion afterwards (Khan et al., 2019). In the light of this information, the antecedents of alienation to work can be explained within the framework of the variables in the Job Demands- Resources model. The purpose of this study is to examine the direct and indirect effects of job autonomy, role conflict and organizational justice variables on the IT employees' perception of work alienation.

\section{RESEARCH DESIGN AND METHODOLOGY}

In this study, hypotheses related to variables that directly and indirectly affect the perception of information technology (IT) employees' alienation to work were tested. A descriptive research design was conducted to examine the specific effects revealed in this context. The hypotheses included in the research model developed within the scope of the literature review are presented below:

$\mathrm{H}_{1}$ : Job autonomy perceptions of IT employees positively affect their perceptions of procedural justice.

$\mathbf{H}_{2}$ : Job autonomy perceptions of IT employees negatively affect their perception of role conflict.

$H_{3 a}$ : Procedural justice perceptions of IT employees negatively affect their perception of powerlessness.

$H_{3 b}$ : Procedural justice perceptions of IT employees negatively affect their perception of self-alienation.

$\boldsymbol{H}_{3 c}$ : Procedural justice perceptions of IT employees negatively affect their perception of meaninglessness.

$H_{4 a}$ : Role conflict perceptions of IT employees positively affect their perception of powerlessness.

$H_{4 b}$ : Role conflict perceptions of IT employees positively affect their perception of self-alienation.

$H_{4 c}$ : Role conflict perceptions of IT employees positively affect their perception of meaninglessness. 


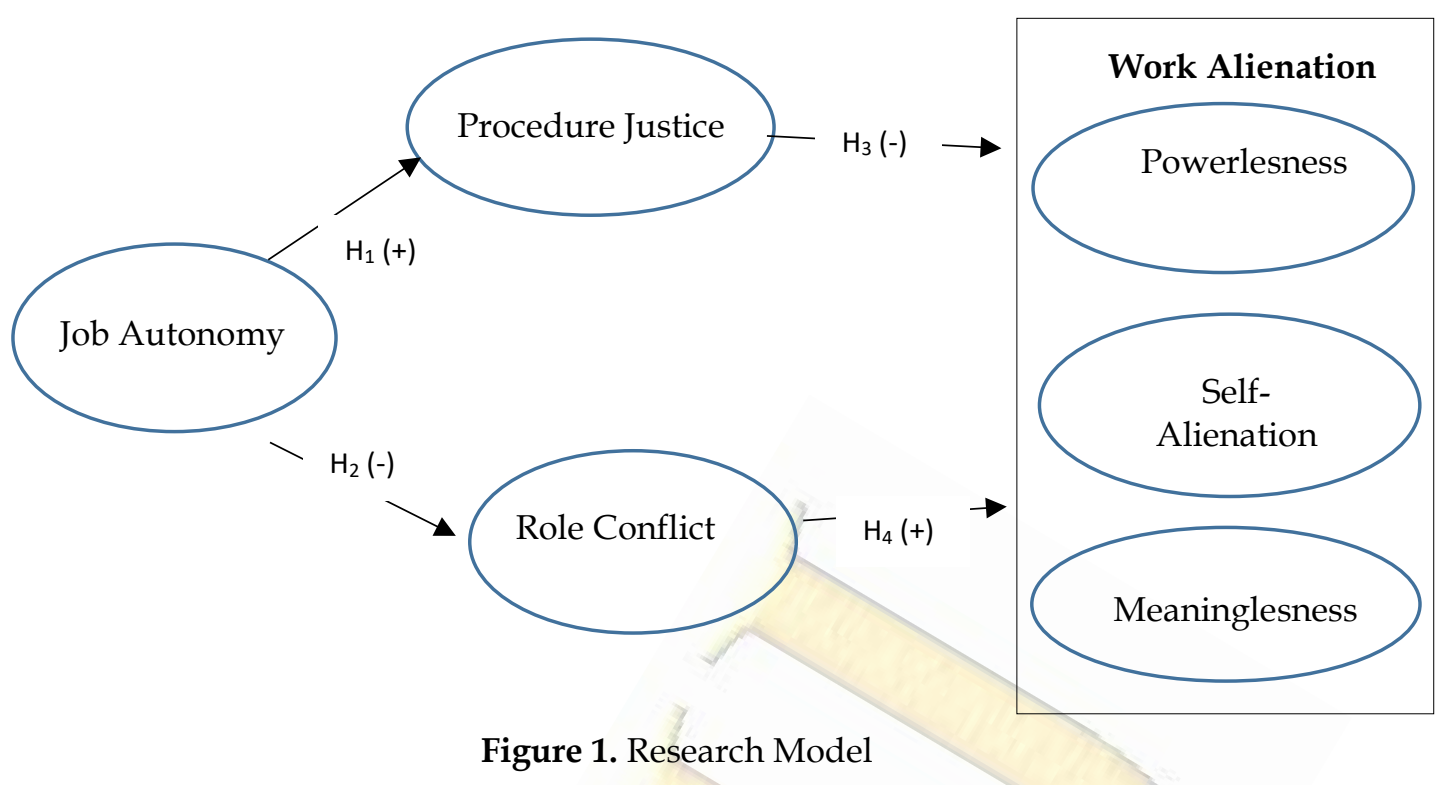

The sample was drawn from different organizations in the information technology sector in Istanbul, Turkey's largest metropolitan city, based on purposive sampling. The sample comprised IT employees working in different areas such as software, hardware, programmers, data analysis etc. Data were collected from 172 IT employees across seven medium- sized and small companies. Since it was necessary to obtain data from a wide sample to test the hypotheses included in the research model, a questionnaire was chosen as a data collection tool. Considering that it would be more convenient to reach IT employees who are experts in the use of technology with an online questionnaire and that the questionnaire would be answered more easily by the participants, the questionnaire was designed via the internet.

The designed questionnaire consists of two parts. In the first part, the scales related to the variables in the research model are presented, in the second part, there are questions about demographic characteristics. To measure work alienation, the scale developed by Mottaz (1981) and adapted and revised in Turkish by Sayü (2014) was used. Considering the previous studies in the literature on IT employees, it was decided in this study that only the procedural justice sub-dimension of the organizational justice was included in the research model. The scale developed by Colquitt et al. (2001) was used to measure procedural justice. Work autonomy scale was taken from Lim's (2008) study. The scale developed by Rizzo, House and Lirtzman (1970) was based on to measure the role conflict perceived by IT employees.

\section{ANALYSIS AND FINDINGS}

A process consisting of three stages was followed in order to test the research hypotheses by modeling structural equations. Confirmatory Factor Analysis (CFA) was performed to evaluate the psychometric suitability of the measurements made in the first stage. Whether the scales used in this way are compatible with the dimensions used in the literature and previously used were examined statistically. In the second stage, the relationships between the structures were examined by making validity and reliability analyzes. In this context, internal consistency reliability (by examining Cronbach Alpha and CR = Composite Reliability values), convergent validity (factor loads and AVE = Average Variance Extracted values are examined) and discriminant validity was analyzed using the criteria proposed by Fornell and Larcker (1981) and the HTMT criterion proposed by Henseler et al. (2015).

In the structural equation model analysis, partial least squares path analysis (PLS-SEM) was used. The collected data were analyzed with the Smart PLS 3.2.8 program (Ringle et al. 2015). In the analysis process, PLS algorithm is used to calculate the linearity, regression, path coefficients and effect size (f2) between structures. Resampling (bootstrapping) and 5000 sub-samples were selected from the sample and $t$ values were calculated, and the predictive power (Q2) was examined using Blindfolding analysis. 
$\mathrm{H} 1$ and $\mathrm{H} 2$ hypotheses were accepted according to the findings of standard deviation, $\mathrm{t}$ value and significance related to direct effects in the model analyzed. $\mathrm{H} 3 \mathrm{a}, \mathrm{H} 3 \mathrm{~b}$ and $\mathrm{H} 3 \mathrm{c}$ hypotheses of the model were accepted. The significance ( $p>0.001)$ value of the model's H3a hypothesis was not supported because it was not appropriate, and the $\mathrm{H} 3 \mathrm{~b}$ and $\mathrm{H} 3 \mathrm{c}$ hypotheses were supported. Among indirect effects, work autonomy does not indirectly affect perception of powerlessness, perception of self-alienation and meaninglessness through role conflict. H6a H6b and H6c hypotheses were not supported, in all three hypotheses since the significance ( $p>0.001)$ values were not suitable. H5a, H5b and $\mathrm{H} 5 \mathrm{c}$ hypotheses were supported according to the significance $(\mathrm{p})$ values.

\section{CONCLUSION}

In this study; within the scope of the Job Demands - Resources Model, the relationships between the variables of job autonomy, role conflict, procedural justice, and work alienation were analyzed. For this purpose, the results of the research model tested using the structural equation model showed that the variables of job autonomy, role conflict and procedural justice have the power to predict employees' perception of alienation to work. The findings of the study showed that job autonomy indirectly affects perceptions of powerlessness, self-alienation and meaninglessness through procedural justice. Another finding obtained in the study is that role conflict positively affects alienation to work. Therefore, a conflict between the employees' self-expected roles and the role they believe should be in line with their qualifications and expertise can dismiss the employee from work. According to the Job Demand- Resource Model, role conflict in the demand category (Demerouti \& Bakker, 2011) is an important source of alienation for both managers and employees (Arslan \& Üngüren, 2017). Similarly, Michaels et al. (1996); Agarwal (1993, p. 732) and Korman et al. (1981) found that role conflict increases alienation to work.

The development and growth of the IT sector, which acts as a locomotive in the development of a country's economy, and the ability of the companies operating in this sector to pay for their investments are directly related to the motivation of the sector employees. In this context, it is critical to develop various support programs and incentives to demonstrate the career development and expertise of sector employees.

This study was conducted with a sample that can be considered small due to time and cost constraints. More detailed inferences can be made for the IT sector by using a larger sample and different variables related to the workplace environment in future studies. This study focuses more on the antecedents of alienation to work. However, there is also a need for studies that examine the consequences of work alienation, such as burnout and deviation. 


\section{GİRIŞ}

Sanayi devriminden beri birçok alanda en kritik yapısal değişimler bilgi teknolojilerinin hızla ilerlemesiyle gerçekleşmektedir. Teknolojinin gelişimi ve internetin yaygınlaşması, üretim basamaklarını birbirinden ayırmakta ve üretim faaliyetlerinin farklı yerlerde gerçekleşebilmesini mümkün kılmaktadır. Hızla gelişen bilgi teknolojileri sektörü, hemen hemen tüm sektörlere ve günlük hayata girerek kendine özgü bir iş alanı olmasının yanında tüm sektörlerin verimlilik, ARGE ve yenilik faaliyetlerini etkiler hale gelmiştir. Bilgi teknolojileri kapsamında gelişmiş ülkeler pek çok alanda rekabet gücü avantajı elde etmektedir. Teknolojiye yatırım yapan ve bu alanda ilerleyen ülkelerin ekonomik açıdan daha gelişmiş ve daha az dışa bağlı kalabildikleri gözlenmektedir. Ekonomik büyüme konulu araştırmalar, bilgi teknolojilerine yönelik yatırımların büyüme üzerinde doğrudan etki yarattığını göstermektedir. Bilgi teknolojileri kullanımının ekonomideki verimlilik artışının yaklaşık yüzde 80'ini tek başına gerçekleştirdiği ifade edilmektedir (İmamoğlu ve Soybilgen, 2014). Diğer bir ifade ile bilgi teknolojileri sektörü, "Sanayi, Teknoloji ve İstihdam" konularında tüm dünyada en hizlı gelişen ve kritik önemde bir sektör olmuştur.

Bilgi teknolojileri temelli endüstrilerin yarattığı katma değer ve yüksek istihdam potansiyeli dikkate alındığında, gelişmekte olan ülkelerin ekonomik gelişmede fark yaratabilmeleri için bilgi teknolojileri sektörüne yatırım yapmaları önemli bir önceliktir. Bu kapsamda bilgi teknolojileri sektörü, ekonominin yeni itici gücü olarak değerlendirilmekte ve dolayısıyla "stratejik sektör" olarak tanımlanmaktadır. Artık bilgi stratejisi, ülkelerin kalkınma programının ayrılmaz bir parçası olarak kabul edilmektedir. Böylesine stratejik önemi olan sektörün en önemli bileşeni ise eğitimli ve uzman, BT çalışanlarıdır. Dünya genelinde BT çalışanlarının toplam istihdam içindeki payları incelediğinde; OECD ülkelerinde bu oranın \% 2 ile \% 5 arasında değiştiği görülmektedir. Türkiye' de ise bu oran \% 1,7'dir (Özkan, 2016). Bilgi Sanayicileri Derneğinin (TÜBİSAD) 2018 yılı “Türkiye Bilgi ve İletişim Teknoloji Sektörü Pazar Verileri" ne göre, sektörün toplam ekonomik büyüklüğü, 31,7 milyar TL'dir ve sektörde yaklaşık 130 bin çalışan istihdam edilmektedir (TUBİSİAD, 2019). 
Öte yandan, ülkemizde bilgi teknolojileri sektörüne yönelik işgücü talebi artmakta, yeni meslek tanımları ve nitelik gereksinimleri oluşmaktadır.

Sektörün büyümesinde ve istihdam oranlarında artış hızla devam ederken, pek çok sektörde olduğu gibi bu sektörde de çalışanların kurumsal olmayan uygulamalar nedeniyle psikososyal risklerle karşı karşıya kalmaları, ciddi bir sorun teşkil etmektedir. Sektörle ilgili yapılan araştırmalara göre, süreklilik gösteren olumsuz tutum, davranış ve uygulamalar yüzünden çalışanlar olumsuz yönde etkilenmektedir. Bu kapsamda BT çalışanlarının işlerine yönelik olumsuz tutumlarının altında yatan nedenlerin belirlemesine yönelik araştırmalara ihtiyaç duyulmaktadır. Çalışanlar, sektörün dinamik ve sürekli değişen yapısı nedeniyle, işlerini yürütürken güncel kalabilmek adına sürekli öğrenmek ve yeni beceriler kazanmak durumundadır. Aynı zamanda uzmanlıkları ve yaratıcılıklarını rahatlıkla sergileyebilecekleri çalışma ortamlarına ihtiyaç duymaktadırlar. Aksi takdirde mevcut nitelikleri değer kaybetmekte, yetersiz kalmakta ve sonuçta verimlilikleri düşmektedir (Chilton, Hardgrave ve Armstrong, 2010). Tüm bu bilgiler ışı̆̆ında, bilgi teknolojileri sektörünün önemi ve kendine has iş özellikleri gereği sektör çalışanlarının iş ortamlarını olumlu ve olumsuz yönde etkileyen faktörlerin araştırılması son derece önemlidir. Özellikle, geleneksel iş platformlarının sunmuş olduğu rapor merkezli yaklaşımlar, hantal ve karmaşık altyapılar, iş yükü, iş birimlerinden gelen analitik uygulama taleplerinin hızlı biçimde yerine getirilmesi konusundaki baskılar, bilgi teknolojileri sektörü çalışanlarının kendi uzmanlık alanlarına zaman ayırmalarını engellemektedir. Sonuç olarak bu geleneksel sistem, çalışanlarda hayal kırıklıklarının oluşmasına ve devamında işlerine karşı yabancılaşma yaşamalarına neden olabilmektedir. Bu doğrultuda çalışmanın amacı, BT çalışanlarının iş ortamını oluşturan; iş özerkliği, rol çatışması ve örgütsel adalet değişkenlerinin sektör çalışanlarının işe yabancılaşma algıları üzerindeki doğrudan ve dolaylı etkilerini incelemektir.

\section{KURAMSAL ÇERÇEVE}

İşe yabancılaşmanın öncüllerini belirlemede Demerouti ve diğ. (2001) tarafından geliştirilen, temel olarak çalışanların iş ortamındaki verimliliği, esenliği 
için gerekli faktörleri açıklamayı amaçlayan, “İş Kaynak-Talep Modeli” açıklayıcı bir bakış açısı sağlamaktadır. Söz konusu model; çalışma koşullarını, iş talepleri ve iş kaynakları olarak iki temel başlıkta sınıflandırmaktadır (Turgut, 2011, s.157). İş talepleri, çalışanların sorun şeklinde tanımladığı, fiziksel ya da psikolojik gayret gerektiren, iş ortamındaki koşullardır. Örneğin; iş yükü, uzun çalışma saatleri, zaman ve çalışma baskısı, rol çatışması ve iş güvencesi gibi faktörler iş talepleri ile ilişkilidir (Rothmann ve Jordaan, 2006, s.88). Modelde öne sürülen kaynaklar ise, çalışanın örgütsel ve bireysel amaçlara ulaşmasını destekleyen, işle ilgili zorlu koşulları ve bu koşulların yarattığı stresi azaltan, örgütsel faktörlerdir (Demerouti ve diğ., 2001). Çalışanların kariyerlerini gerçekleştirme, öğrenme ve gelişmeleri için destekleyici iş koşullarından oluşur (Baker ve Demerouti, 2007). Bu koşullara; maaş veya ücretler, ödüllendirme, yönetici desteği, kontrol, özerklik, kararlara katılım şeklinde örnek verilebilir (Agarwal, 2014). Bir iş ortamında, iş kaynakları ve iş taleplerinin dengesiz olması başta tükenmişlik ve işe adanmışlı̆̆ın azalması gibi olumsuz sonuçlara neden olacaktır. Benzer biçimde, iş talep-kaynaklarındaki dengesizliğin çalışanların işe yabancılaşmasına neden olması da muhtemeldir.

İş Talep-Kaynak Modelinin savunduğu temel varsayım, hali hazırdaki iş kaynaklarının, iş taleplerinin çalışan üzerindeki etkisini azalttığı yönündedir (YüceSelvi ve Sümer, 2018). İş talepleri ve iş kaynaklarının çeşitli şekillerde birleşmesiyle ortaya çıkan iş özellikleri, çalışanlarda birbirinden farklı psikolojik durumlar ve tutumların oluşmasında öncü rol oynamaktadır. Çalışan yüksek iş taleplerine karşı, iş kaynaklarından yoksun kalırsa, işten uzaklaşma davranışı sergiler (Başoda, 2017). Marx, yabancılaşmış çalışanların, "fiziksel ve zihinsel güç edinme yeteneğinden yoksun kaldıklarını, bunun yerine fiziksel ve zihinsel olarak tükenmişlik hissine kapıldıklarını iddia eder (Khan ve diğ., 2019). Bu argümana dayanarak, Conway ve diğ. (2018) çalışmalarında, işe yabancılaşma ve tükenmişlik arasındaki ilişkiyi ele almışlar ve yabancılaşmanın tükenmişliğin duygusal tükenme boyutunu artırdığını ortaya çıkarmışlardır. İşe yabancılaşma, çalışanın engel olarak algıladığı çeşitli iş talepleri sonucu ortaya çıkmaktadır. İş talep kaynak modeline göre bu durum, devamında duygusal açıdan tükenmeye yol açmaktadır (Khan ve diğ., 2019). Tüm bu 
bilgiler 1şı̆̆ında işe yabancılaşmanın öncüleri iş talep- kaynak modelinde yer alan değişkenler çerçevesinde açıklanabilir.

\section{LİTERATÜR İNCELEMESİ}

\section{1. İşe Yabancılaşma}

Yabancılaşma kavramı ilk kez Hegel (1910) tarafından, bireyin çevresinden ve kendi benliğinden kopması şeklinde tanımlanmıştır. Daha sonra bu kavram, Marx (1844/1975) tarafından sosyal ve ekonomik açıdan detaylı şekilde irdelenmiştir. Marx, kapitalist emek sürecinin işçiler üzerindeki etkilerini açıklamaya çalışırken, her insanın doğasında yaratıcı eylemin yer aldığını, dolayısıyla bu eylemi gerçekleştirebilecek ortamlara ihtiyaç duyduğunu ifade etmiştir. Marx'a göre bireyler bu ihtiyaçlarını en çok işlerinde karşılayabilirler, eğer emekleri üzerindeki kontrollerini kaybederlerse yabancılaşma duygusu yaşayacaklardır (Mottaz, 1981). Varlığını korumak ve refahını sağlamak için çalışmak, üretmek ve değer yaratmak, insanın doğası gereğidir. Dolayısıyla işte vakit geçirmek, insan yaşamının önemli bir kısmını oluşturur. Bu özelliği ise, onu değer yarattığı işi ve iş çevresiyle özel bir ilişki kurmaya yönlendirir (Mottaz, 1981, s.515). Öte yandan, bireyin üretilen ve devamında değer yaratılan süreç üzerinde kontrolünü kaybetmesi, işin anlamını kaybetmesine neden olur. Bu durum ise, çalışanın iş ortamı ile bağlarının zayıflaması sonucunu doğurur (Maddi, 2004).

Marx yabancılaşmayı, 1844 yılında yazdı̆̆ı "Elyazmaları" isimli eserinde, “insanın yaratıcılığının kısıtlanması" olarak ele almıştır (Çelik, 2011, s.16), yabancılaşma kavramını açıklarken, emek süreci üzerinde durmuştur (Kaya ve Serçeoğlu, 2013). Kapitalist sistemin ortaya çıkardı̆̆ı emek-sermaye ilişkisinin, çalışanın yaratıcılığını engellediğini ve çalışmayı anlamsız bir eyleme dönüştürdüğünü, bu nedenle yabancılaşmanın bu sistemin bir parçası olarak kaçınılmaz olduğunu vurgulamıştır (Marx, 1844/1975). Emeğin sergilenmesi sürecinde, çalışan emeğini ücret karşılığında bir sermayedara satar. Ana amacı kâr elde etmek olan ve emeği satın alan sermayedar ise, maliyetleri azaltacak ve verimliliği artıracak şekilde işleri organize eder. Bu süreçte şekillenen modern çalışma ortamında; aşırı iş bölümü ve yetkinin resmi otoritede toplanması söz 
konusu olur. Bu süreç neticesinde çalışan, üretim sürecindeki ve ürettiği ürünün kaderindeki kontrol hakkını kaybeder. Çalışan, becerilerinin özgürce sergilenmesini ve geliştirilmesini sınırlayan bu ortamda, çalışma kavramını onur kırıcı ve eziyet verici bir durum olarak algılar. Devamında ise çalışan, ürettiği ürüne, çalışma arkadaşlarına ve devamında kendi benliğine yabancılaşır (Shantz, Alfes ve Truss, 2014).

Marxist görüşte yabancılaşma, öznel bir ruh durumundan ziyade, sistemin yarattı̆̆ı nesnel bir gerçekliktir. Yabancılaşmayı ele alan devamındaki araştırmalar ise, psikolojik bir yaklaşım olan "varoluşçu düşünce" üzerinde durmuşlardır. Bu yaklaşıma göre yabancılaşma, insan yaşamının kaçınılmaz bir parçasıdır ve nesnel çalışma koşullarının neden olduğu öznel duygu durumudur (Mottaz, 1981). Bu duygu durumunda çalışan; duygu, zihin ve beden bütünlüğünün bozulduğunu hisseder ve bu his giderek derinleşir. Bu derinleşme, “insanın çevresinden, işinden, emeği ile yarattığı ürününden, kişiliğinden uzaklaşma ya da ayrılma duygusunu dile getirmektedir" (Öcal ve Barın, 2016). Böylece "bireyin toplumsal, kültürel ve doğal çevresine olan uyumunun azalması hem toplumsal hem de iş çevresi üzerindeki denetiminin etkisiz hale gelmesi, giderek yalnızlık ve çaresizlik hissine kapılmasına neden olmaktadır" (Tükel, 2012, s.39). Yabancılaşma literatürüne önemli katkılar sağlayan Blauner (1964), yabancılaşmayı “işin özerklik, sorumluluk, toplumsal etkileşim ve kendini gerçekleştirme gibi, bireyin insan olarak değerini ortaya koyan koşulların sağlanamaması durumu" biçiminde tanımlamıştır (Hull, Friedman ve Rogers, 1982, s.32),

Literatürde yabancılaşma kavramı farklı şekillerde boyutlandırılmıştır, ancak en geçerli sınıflandırma, Seeman'a aittir. Seeman, “On The Meaning of Alienation (Yabancılaşmanın Anlamı Üzerine)" adlı çalışmasında yabancılaşmayı; "güçsüzlük duygusu (powerlessness)", "normsuzluk (normlessness)", “anlamsızlık duygusu (meaninglessness)", “yalıtılmışlık duygusu (isolation)" ve "kendine yabancılaşma (self-estrangement)" olacak şekilde beş boyutta ele almıştır (1959, ss.783-791). Seeman'dan sonra Blauner'da yabancılaşmayı, "güçsüzlük”, "anlamsızlık”, "yalıtılmışlık" ve "kendine yabancılaşma" olmak üzere dört boyutta açıklamıştır (1964, s.18-26). Devaminda Mottaz, yedi farklı meslek grubunu temsil eden 1.331 
çalışan üzerinde yürüttüğü çalışmasında, Seeman'ın beş boyutlu yabancılaşma modelinin üç boyutunu (güçsüzlük, anlamsızlık ve kendine uzaklaşma) temel alarak; işe yabancılaşmanın kaynağını araştırmaya çalışmıştır (Mottaz, 1981, ss.515-529).

Tüm bu bilgiler ışığında araştırmada yabancılaşmanın; güçsüzlük, kendine yabancılaşma ve anlamsızlık boyutları ele alınmıştır. Güçsüzlük (powerlessness), çalışanın ürettiği ürün ve üretim esnasındaki faaliyetlerinde söz hakkının olmamasıdır (Seeman (1959, s.786). Diğer bir ifade ile “yapılan iş üzerindeki kontrol ve özgürlüğün yokluğudur" (Shepard, 1971, ss.13-14). Anlamsızlık (Meaninglessness), çalışanların yaptığı işe bir anlam verememesi, bağlı oldukları örgütün amaçlarını ve yaptıkları işlerin birbiriyle olan ilgisini kavrayamamasıdır (Kanungo (1982b, s.26). Böyle bir durumda çalışan, üretim sürecine katkısının ve kontrolünün çok az olduğuna inanmaktadır (Mottaz, 1981, ss.516-517). Kendine yabancılaşma (selfestrangement) ise, Fromm tarafından, "Sağlıklı Toplum" adlı eserinde, "kişinin kendini bir yabancı olarak görmesi" şeklinde tanımlanmıştır (1955, s.120). Marx'a göre, kapitalizm ile ortaya çıkan seri üretim sistemi, çalışanın özgürlüğünü elinden almaktadır. Dolayısıyla çalışan emek sarf ettiği ürüne kendisinden bir şey katamamakta ve kendine yabancılaşmaktadır (Kuru, 2009, s.15). Seeman ise, Marx'ın kendisine yabancılaşan birey tanımını, çalışanın çalışma ortamında kendisini rahat, “evinde" hissetmemesi şeklinde açıklamıştır (1959, s.787). Seeman'a göre kendine yabancılaşma hissi, "bireyin herhangi bir davranışının, geleceğe dönük beklentileri ile uyuşmaması, kişinin bu beklentilerinin dışına çıkarak farklı davranmasıdır" (1959, ss.789-790). Bu durumda çalışan, işinden bir doyum sağlayamamakta ve işini sadece bir araç olarak görmektedir (Blauner, 1964, ss.18-26).

\section{2. İş Özerkliği}

Çalışma ortamında özerklik, çalışanların görevlerini nasıl yerine getirecekleri konusunda karar verme özgürlükleri ve işleri üzerinde kontrol sahibi olmaları şeklinde tanımlanmaktadır (Tolay, Sürgevil ve Topoyan, 2012, s.452). Özerkliğe sahip olan çalışanlar, iş ortamında problemler ile baş etme konusunda yeni yöntemler geliştirebilirler (De Jong ve Kemp, 2003:190). Çalışanlara bağımsız düşünerek faaliyette bulunmalarına olanak tanınması, öz yeterliliklerinin gelişmesine ve yaratıcı 
çalışmaların ortaya çıkmasına yardımcı olur (Gümüşlüoğlu ve Ilsev, 2009, s.462). Diğer taraftan, üretim sürecinde kontrol ve özerklikten yoksunluk; yönetimle ilgili kararlarda fikir beyan edememek ve işin denetiminde yer alamamak çalışanda güçsüzlük hissi doğurur (Blanur, 1964). Güçsüzlük hisseden çalışanlar, hayatlarına kendi iradelerinden ziyade sistemin veya üst konumlarda yer alanların karar verdiği şeklinde bir duyguya kapılırlar. Dolayısıyla özsaygı, kendini gerçekleştirme ve özerklik ihtiyaçlarını gideremez ve işlerine karşı yabancılaşırlar (Turgut ve Kalafatoğlu, 2016, s.31). Kanungo (1992, s.416) işe yabancılaşmayı, çalışanın üretim süreçleri üzerindeki kontrolünden, çalışma arkadaşları ve müşteriler ile etkileşiminden ve bireyin yeteneklerinden mahrum bırakan iş koşulları olarak tanımlamıştır. Özellikle, merkezileşmenin ve biçimsel ilişkilerin yoğun düzeyde olduğu örgüt yapılarında hem işe hem de sosyal etkileşime yabancılaşma artmaktadır (Aiken ve Hage 1966, s.504). Yapılan araştırmalar, işe yabancılaşmanın genelde işteki özerkliği ve kararlara katılımı kısıtlayan merkezi, katı kural ve politikaların hâkim olduğu yapısal koşullardan kaynaklandığı ortaya çıkarmıştır (Ramaswami, Agarwal ve Bhargava, 1993).

İş talep kaynak kuramına göre, çalışma ortamlarında çalışanlara işleri ile ilgili seçim yapma ve karar verme yetkisi verilmesi, çalışanların işlerine karşı olumsuz tutumlar geliştirmelerini önleyebilir. Böylece çalışandan beklenen talepler fazla olsa bile, çalışan bu talepleri kontrol edebileceğine ilişkin inanç geliştirebilir. Sonuç olarak yetki ve sorumluluklarını özgürce kullanabilir, parçası olduğu örgüte karşı bağlılı̆̆ı güçlenir. Bakker (2011) çalışmasında, iş kaynaklarının çalışanın işe adanma tutumu geliştirmesinde önemli bir etken olduğunu öne sürmektedir. Bu kaynaklar, çalışanlardan talep edilen yüksek iş performanslarına karşı koruyucu bir güç oluşturur. Modelde önemli kaynaklar arasında gösterilen özerklik, çalışanların iş süreçlerini kontrol etmede yeteneğini sergileme fırsatı vererek, iş ve hayat tatmini sağlamaktadır (Hobfoll ve diğ., 2003). Bu nedenle, iş özerkliği çalışanların işe katılımını etkileyen potansiyel bir iş kaynağı faktörüdür (Taştan, 2014). Bakker ve Demerouti (2007), iş özerkliği arttıkça, çalışanların yaptıkları işte daha fazla kişisel sorumluluk hissettikleri ve işlerinin sonuçlarına katkıda bulunmaya daha istekli olduklarını dile getirmiştir (Atilla Bal, 2008). Öte yandan, daha öncede ifade edildiği 
gibi, sorumlu olunan iş süreçleri için gerekli özerklik imkanının sunulmaması, işe yabancılaşmayı artırıcı bir etki yaratacaktır (Thibaut ve Walker, 1975). Literatürde özellikle özerklik algısının işe yabancılaşma hissi üzerinde etkili olduğunu ifade eden çalışmalara rastlamak mümkündür (Berardi, 2010). Gradney, Fisk ve Steiner (2005), Amerikalı ve Fransız çalışanlar üzerinde yürüttükleri çalışmalarında, çalışma ortamında özerk olduğuna inanan çalışanların daha az güçsüzlük hissi yaşadığını bulgulamışlardır. Benzer şekilde Özkoç (2016), konaklama işletmeleri çalışanlarına yönelik çalışmasında, çalışma ortamındaki özerklik düzeyinin işe yabancılaşma eğilimi üzerinde direkt etkili olduğunu belirlemişlerdir. Tüm bu bilgiler çerçevesinde, iş özerkliğinin yabancılaşmada etkili olması muhtemeldir.

\subsection{Rol Çatışması}

Rol çatışması "aynı anda birden fazla rolü gerçekleştirmek durumunda olan bireyin, rol gereklerinden birisine, diğerine oranla daha fazla uyması" ve buna ilave olarak "bireyin yüklendiği rollerin ya da farklı bireylerin rollerinin çatışması" halidir (Gökçe ve Şahin, 2003, s.146). Gullahorn rol çatışmasını, “bireyden rol ilişkileri kapsamında beklenen, birbiriyle bağdaşmayan taleplerin yarattığı durum" şeklinde tanımlamıştır (1956, s.299). Bu durumda birey, birbiriyle çatışma halinde olan rol beklentilerini yerine getirme baskısına maruz kalmakta ve başarısızlık ihtimalinde karşılaşması olası yaptırımların tehdidini hissetmektedir. Devamında ise birey, stres yaşamakta ve doğal olarak performansı olumsuz etkilenebilmektedir (Fisher, 2001; Behrman, 1984).

İş Talep-Kaynak Modeli'nde rol çatışması, önemli iş talepleri arasında yer almaktadır (Demerouti ve Bakker, 2011). Bu çatışma türü, çalışanların örgütleri için üstlendikleri çoklu görevler neticesinde yaşadıkları bir stres kaynağıdır (Bryant ve Constantine, 2006). Çalışma ortamında yeterli özerkliğe sahip olmayan çalışanlar, asıl rollerini gerçekleştirme konusunda bir engelle karşılaştıklarını düşünerek, işlerini başarılı bir şekilde gerçekleştiremediklerine dair bir inanç geliştirmektedirler. Bunun sonucunda ise, iş statülerini kaybetme korkusu nedeniyle çalışma rollerine ek kaynaklar yatırmak zorunda kalmaktadırlar (Jawahar, Stone ve Kisamore, 2007). Algılanan rol çatışmasının bir sonucu olarak, çalışma rolüne ek bir kaynak yatırımı 
ise, memnuniyetsizlik ve psikolojik gerginlik gibi olumsuz durumlara yol açmaktadır (Jawahar ve diğ., 2007; Turgut, 2011).

İlgili alan yazın incelendiğinde, görev çeşitliliği ve görevin kimliğinin de işe yabancılaşmanın öncüllerinden olduğu görülmektedir (Shantz ve diğ., 2015). Çeşitli görevleri yapmaktan zevk duyan ve işini örgütün amaçlarıyla bağdaştırabilen bireylerin işe yabancılaşma olasılığı düşük olmaktadır (Atay ve Gerçek, 2017, s.325). Diğer taraftan, işin gerektirdiği roller ile çalışanın kendi öz doğası arasında yaşanan uyuşmazlık, yabancılaşmaya yol açmaktadır (Mottaz, 1981, s.515). Chiaburu Thundiyil ve Wang (2014, s.27) işe yabancılaşmanın sebep ve sonuçlarını ortaya koymayı amaçladıkları araştırmalarında, rol çatışması ve yabancılaşma arasında doğrudan, pozitif yönlü bir ilişki olduğunu belirlemişlerdir. Benzer şekilde Michaels ve arkadaşları (1996), Amerika, Japonya ve Kore' de çalışan satış görevlileri üzerinde yürüttükleri çalışmalarında, rol çatışmasının işe yabancılaşma üzerinde etkili olduğunu belirlemişlerdir. Bir diğer çalışma ise, Agarwal (1993, s.732) tarafından gerçekleştirilmiştir. Araştırmacı bu çalışmasında, rol çatışmasının yabancılaşmaya olan etkisinin farklı kültürlerde değişip değişmediğini belirlemeye çalışmıştır. Çalışma sonucunda, ABD'de satış görevlilerinde rol çatışmasının, yabancılaşmada öncü olmadığı, çalışmanın Hindistan örneklemindeki satış görevlileri için işe yabancılaşmaya neden olduğu gözlenmiştir. Yine Korman, Wittig-Berman ve Lang (1981) yöneticilerin ve uzmanların iş ortamında yabancılaşma hissi yaşamalarında etkili olan faktörleri inceledikleri araştırmalarında, birbiriyle çelişen rol sorumluluklarının işte yabancılaşmaya yol açtı̆̆ını belirlemişlerdir.

Rol çatışması ve işe yabancılaşmanın boyutları arasındaki ilişkileri ele alan çalışmaları incelendiğinde; Chiaburu, Thundiyil ve Wang'ın (2014) işe yabancılaşmayı etkileyen faktörleri belirlemek için 1.200 akademik çalışmayı inceledikleri meta analizde; rol çatışması ve rol belirsizliğinin, işe yabancılaşmanın üç boyutu üzerinde pozitif etki yarattığını öne sürmüşlerdir. Türkiye'de Arslan ve Üngüren (2017) tarafından belediye çalışanları üzerine yürütülen çalışmada, rol çatışmasının "güçsüzlük" boyutu üzerinde anlamlı bir etki yarattığını tespit etmişlerdir. Benzer şekilde Tokgöz (2019), kamu kurumu çalışanlarına yönelik araştırmasında, rol çatışması ve rol belirsizliğinin; "anlamsızlaşma", "kendine 
yabancılaşma" ve "güçsüzlük" boyutları üzerinde istatistiksel olarak anlamlı bir etkiye sahip olduğunu belirlemiştir. Tüm bu bilgiler değerlendirildiğinde, rol çatışmasının hem yöneticiler hem de çalışanlar açısından, önemli bir iş tatminsizliği ve yabancılaşma kaynağı olduğu ifade edilebilir.

Rol çatışması, yabancılaşma üzerinde doğrudan bir etki yaratmakla birlikte çalışma ortamındaki merkeziyetçi yapının örgütsel yabancılaşma üzerindeki etkisinde aracı bir rol de oynayabilmektedir. Organ ve Greene (1981), bilim adamları ve mühendislere yönelik araştırmalarında, örgütün merkezi yapısının rol çatışmasını arttırdığını ve yabancılaşmaya neden olduğunu ortaya koymuşlardır. Merkeziyetçi örgüt yapılarında çalışanların işlerinde özerkliğe sahip olması sınırlı düzeydedir. Dolayısıyla rol çatışması işe yabancılaşma ve özerklik arasında da aracı bir etki oluşturabilir. Zira literatüre baktığımızda pek çok çalışma, iş özerkliği ve rol çatışması arasında bir ilişkinin var olduğunu desteklemektedir (Agarwal, 1993; Coelho, Augusto ve Lages, 2011). Örneğin De Ruyter, Wetzels ve Kleijnen (2001) çalışmalarında, iş özerkliğinin rol çatışmasını azaltıcı bir etki yaratığını bulgulamışlardır. Benzer şekilde Coelho ve arkadaşlarının (2011) iş özerkliği, rol çatışması ve yaratıcılık arasındaki ilişkileri inceledikleri çalışmalarında, özerk olmayan çalışma ortamının, rol çatışmasına ve yaratıcı faaliyetlerin azalmasına neden olduğunu ortaya çıkarmışlardır. Tüm bu bilgiler ışığında, işe yabancılaşmada rol çatışmanın işe yabancılaşma üzerinde anlamlı bir etki yaratabileceği, aynı zamanda özerkliğin yabancılaşma ve rol çatışması ilişkisinde aracı etki oluşturabileceği varsayımı geliştirilebilir.

\subsection{Prosedür Adaleti}

Örgütsel adalet, çalışanın bünyesinde yer aldığı örgütün uygulamalarına yönelik algıladığı adalettir (Moon ve diğ., 2008, s.85). Çalışan belli bir örgüte dahil olurken, bilgi ve becerilerini sermaye olarak yanında getirmekte ve zaman içerisinde bu yetkinliklerini örgütsel amaçları gerçekleştirmede kullanarak kendi adına yatırıma dönüştürmektedir. Yapılan bu yatırım ise, katkı oranına göre adil ücret, terfi, prim, ikramiye ve tanınma gibi çeşitli kazanımları kapsayan bir beklentiye dönüşür. Bu beklenti ise literatürde yaygın olarak ele alınan ve adalet boyutlarından 
"prosedür adaleti” kavramı ile açıklanmaktadır Prosedür adaleti, örgüt bünyesindeki çalışanların kendileri ile ilgili alınan kararlarda adil bir tutum sergilenip sergilenmediğine yönelik yargılarıdır (Folger ve Konovsky, 1989, s.126). Diğer bir ifadeyle, çalışma koşullarına ilişkin alınan kararlarda, belirlenen strateji ve politikalarda adil olma derecesidir. Bu adalet türü genellikle çatışma durumunu çözme, karar verme ve kaynakların dağıtımı ile ilgili süreçlerin doğru yöntemler ile yönetilmesini sorgulamaktadır (Folger ve Cropanzano, 1998, s.26).

Alınan kararlardaki adalet duygusunun çalışanların bağlılıkları üzerinde olumlu bir etki yaratması beklenir (Blodgett, Hill ve Tax 1997, s.189). Kurumlardaki uygulamaların tutarlı, önyargısız, tarafsız ve etik standartlara dayalı olması, çalışanlarda örgüte karşı bağlılık hissi oluşturur (Özbek ve Umarov, 2010). Çalışan, eğer çalıştığı ortamda bir eşitsizliğin olduğunu gözlemliyorsa, işi ile ilgili tatmin duygusunu kaybedecek ve adalet inancı zedelenmiş olacaktır (Eren, 2007, s.543). Böyle bir durumda ise çalışanlar, örgüte ve yapmış oldukları işe karşı yabancılaşma ve saldırganlık gibi olumsuz tutumlar geliştireceklerdir (St-Pierre ve Holmes, 2010, s.1170). Sookoo (2014) Trinidad'da kamu sektöründe örgütsel adaletsizlik ve işe yabancılaşmanın dinamiklerini ele aldıkları çalışmasında, adaletsiz bir ortamda çalıştıklarına inanan çalışanların, işlerine karşı yabancılaşma hissi yaşadıklarını saptamışlardır. Yine Merkhe (2015), Ammanda, uluslararası okullarda faaliyet gösteren ve yönetici pozisyonunda çalışanların iş ortamında yabancılaşma yaşadıklarını ve bu durumda önemli olan faktörlerden birinin ise, çalışanların prosedür adaleti algısı olduğunu belirlemişlerdir. Benzer şekilde Howard ve Cordes (2010), prosedürel adaletin, işe yabancılaşmayı negatif yönde etkilediğini gözlemlemişlerdir. Ülkemizde yapılan çalışmalar da bu bulguları desteklemektedir; Zengin ve Kaygın (2016) banka çalışanları üzerinde yürüttükleri çalışmalarında, örgütsel adaletin örgütsel yabancılaşma üzerinde negatif bir etki yarattı̆̆ını belirlemişlerdir. Ceylan ve Sulu (2010) sağlık çalışanlarına yönelik çalışmalarında, prosedür adaletinin işe yabancılaşmanın boyutlarından güçsüzlük üzerinde anlamlı bir etki yarattı̆̆ını ortaya çıkarmışlardır.

İş Talep-Kaynak Modeli çerçevesinde prosedür adaleti değişkenini değerlendirdiğimizde, modelde kaynaklar arasında yer alan özerklik, çalışanların 
işyerindeki prosedürlerin adil olarak uygulandığı konusundaki algılarını olumlu yönde etkilemektedir (Demereouti ve diğ., 2001). Bu durumda çalışan, işe ilişkin talepler yüksek olsa bile işine karşı olumlu tutumlar sergileyecektir. Aksi durumda özerklik ve adaletsizlik algısı, bir kaynak eksikliği olarak değerlendirilerek, düşük iş katılımı, yüksek hayal kırıklığı ve tükenmişliğe yol açacaktır (Rothmann ve Jordaan, 2006). Bu noktada ise, çalışanın işlerine karşı yabancılaşması kaçınılmaz olacaktır. Çünkü çalışanlar sorumlu oldukları iş yapma süreçleri ve sonuçları üzerinde doğrudan kontrol sahibi olmak isterler. Eğer bu süreçte yeterince özerk olmadıklarına inanırlarsa, işyerlerinde adalet konusunu sorgularlar (Thibaut ve Walker, 1975). Çalışanlara karşılaştıkları sorun ya da çatışmaların çözümünde görüş ve önerileri ile katılma imkânı sağlandığında, aynı zamanda görev ve sorumluluklarını yerine getirmede özerklik tanındığında kendilerine adil bir tutum sergilendiğini hissetmektedirler (Tyler ve Lind, 2002). Thibaut ve Walker (1978) çalışmalarında, prosedür adaleti teorilerinin temelinde çatışma durumunda çalışanlara çatışmanın çözümüne ilişkin süreçler üzerinde kontrol hakkı ve özerklik tanıyan prosedürlerin daha adil algılandığ Baron (2000), karar verme ile ilgili prosedürlerde çalışanlara söz hakkı verilmesinin, örgütsel kararların adil olarak değerlendirilebilmesi için gerekli olduğunu savunurlar (Çavuş, 2006, s.69). Böylece kendini güçlendirilmiş hisseden çalışanlar, kendilerini daha özerk ve etki sahibi hissedecekler, prosedürler üzerinde kontrol sahibi olduklarına inanacaklardır. Sonucunda prosedürleri adil olarak değerlendirecekler ve örgütlerine yönelik olumlu tutumlar sergileyeceklerdir (Yürür ve Demir, 2011). Diğer taraftan, özerklik sağlamayan çalışma ortamlarında adil olmayan adalet algısı, yabancılaşma gibi olumsuz tutumlar doğurabilecektir (Camgöz ve Ekmekci, 2017).

Örgütsel adalet ve işe yabancılaşma arasındaki ilişkileri ele alan çalışmalar incelendiğinde; Turgut ve Kalafatoğlu'nun (2016) üretim ve hizmet sektörü çalışanlarına yönelik çalışmalarında, "örgütsel adalet" ile "güçsüzlük" ve "kendine yabancılaşma" boyutları arasında negatif yönlü bir ilişki bulgulamışlardır. Ceylan ve Sulu (2010) tarafından sağlık çalışanları üzerine gerçekleştirilen bir başka çalışmada, "prosedür adaleti" ile "güçsüzlük" boyutu arasında anlamlı bir ilişki ortaya 
çıkmıştır. Yine Tekeli'nin (2016) otel işletmeleri çalışanlarını ele aldığı araştırmasında, prosedür adaletinin işe yabancılaşma eğilimlerini ters yönde etkilediğini belirlemiştir. Tüm bu bilgiler 1şı̆̆ında, prosedür adaletinin çalışanların işe yabancılaşma algısını açıklayan bir değişken olduğu öne sürülebilir.

\section{ARAŞTIRMA MODELİ VE HİPOTEZLER}

Çalışmanın araştırma sorusu çerçevesinde yürütülen literatür incelemesi kapsamında şekil 1'de görülen araştırma modeli geliştirilmiş ve değişkenler arasında öne sürülen hipotezler aşağıda sunulmuştur.

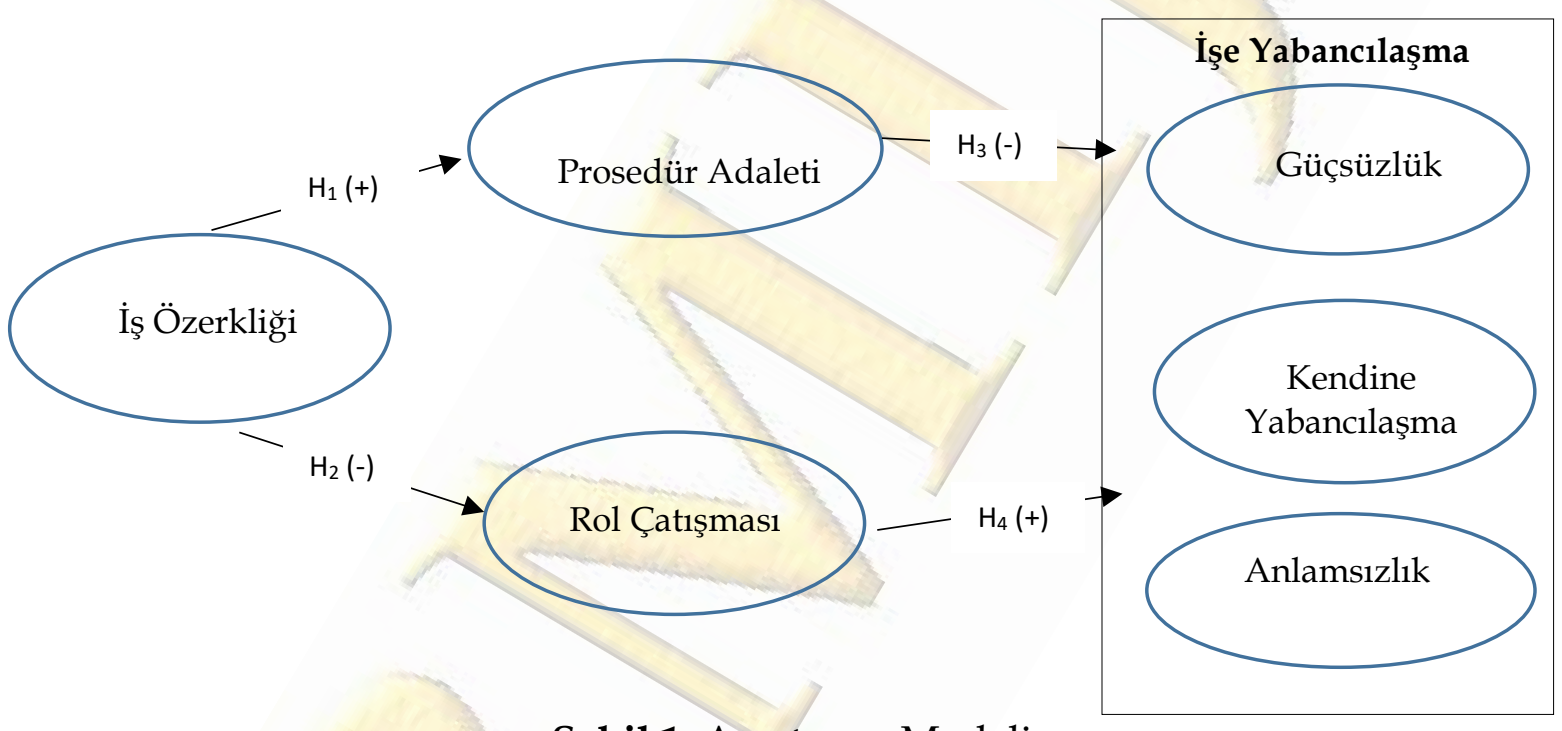

Şekil 1. Araştırma Modeli

$H_{1:}$ BT çalışanlarının iş özerkliği algıları prosedür adaleti algıların pozitif yönde etkiler.

$\mathrm{H}_{2}$ : BT çalışanlarının iş özerkliği algıları rol çatışması algıların negatif yönde etkiler.

$H_{3 a:}$ BT çalışanlarının prosedür adaleti algıları güçsüzlük algılarını negatif yönde etkiler.

$\boldsymbol{H}_{3 b}$ : BT çalışanlarının prosedür adaleti algıları kendine yabancılaşma algılarını negatif yönde etkiler.

$H_{3 c}$ : BT çalışanlarının prosedür adaleti algıları anlamsızlık algılarını negatif yönde etkiler.

$H_{4 a}$ : BT çalışanlarının rol çatışması algıları güçsüzlük algıların pozitif yönde etkiler.

$\boldsymbol{H}_{4 b:}$ BT çalışanlarının rol çatışması algıları kendine yabancılaşma algılarını pozitif yönde etkiler.

$H_{4 c}$ : BT çalışanlarının rol çatışması algıları anlamsızlık algıların pozitif yönde etkiler.

Dolaylı etkiler;

$\boldsymbol{H}_{5 a}$ : BT çalışanlarının iş özerkliği algılarının, prosedür adaleti üzerinden güçsüzlük üzerinde dolaylı etkisi vardır. 
$H_{5 b:}$ BT çalışanlarının iş özerkliği algılarmın, prosedür adaleti üzerinden kendine yabancılaşma üzerinde dolaylı etkisi vardır.

$H_{5 c}$ : BT çalışanlarının iş özerkliği algılarının, prosedür adaleti üzerinden anlamsızlık üzerinde dolaylı etkisi vardır.

$H_{6 a:}$ BT çalışanlarının iş özerkliği algılarının, rol çatışması üzerinden güçsüzlük üzerinde dolaylı etkisi vardır.

$H_{6 b}$ : BT çalışanlarının iş özerkliği algılarının, rol çatışması üzerinden kendine yabancılaşma üzerinde dolaylı etkisi vardır.

$H_{6 c}$ : BT çalışanlarının iş özerkliği algılarının, rol çatışması üzerinden anlamsızlık üzerinde dolaylı etkisi vardır.

\section{ARAŞTIRMA METODOLOJISİ}

$\mathrm{Bu}$ araştırmada bilgi BT çalışanlarının işe yabancılaşma algılarını doğrudan ve dolaylı yönde etkileyen değişkenlere ilişkin hipotezler test edilmiştir. Bu kapsamda ortaya konan spesifik etkileri incelemek üzere tanımlayıcı bir araştırma tasarımı yürütülmüştür.

\subsection{Araştırmanın Örneklemi}

Örneklem, Türkiye'nin ve Dünya'nın gözde ticaret merkezi şehirlerinden olan İstanbul'da BT alanında faaliyet gösteren yedi farklı küçük ve orta ölçekli işletmenin çalışanlarından oluşmaktadır. Söz konusu işletmeler yurt içi ve yurt dışı pazarlara yönelik olarak hizmet vermektedir. Örneklem büyüklüğü saha çalışması sürecinde anketi cevaplamaya gönüllü olan 172 katılımcıdan oluşmaktadır. Araştırmanın konusu ve amacı hakkında katılımcılara detaylı bilgi verilmiştir, saha çalışması 2018 yılında yütürüldüğü için etik kurul belgesi alınmamıştır. Katılımcılar yazılım, donamım, programc1lık, veri analizi gibi farklı görevler yürütmektedirler. Katılımcıların uzmanlık alanları hakkındaki yetkinliklerinden emin olmak amacıyla alanlarında lisans ya da lisansüstü dereceye sahip olmaları ve en az bir yıldır bağlı oldukları şirkette çalışıyor olmalarına dikkat edilmiştir.

\section{2. Ölçekler ve Veri Toplama Süreci}

Araştırma modelinde yer alan hipotezleri test etmek üzere geniş bir örneklemden veri elde etmek gerektiği için veri toplama aracı olarak anket tercih edilmiştir. İşe yabancılaşmanın ölçülmesine yönelik uluslararası literatür 
incelendiğinde farklı yaklaşımlar olduğu görülmüştür. $\mathrm{Bu}$ bağlamda işe yabancılaşmayı ölçmek üzere Mottaz (1981) tarafından geliştirilen ve Sayü (2014) tarafından Türkçe'ye uyarlanan ve revize edilen ölçek kullanılmıştır. Söz konusu ölçek, Türkiye'de Turgut ve Kalafatoğlu (2016) tarafından da kullanılmıştır. Bu ölçek, güçsüzlük (altı madde), anlamsızlık (dört madde) ve kendi kendine yabancılaşma (yedi madde) olmak üzere üç alt boyuttan ve toplam 17 ifadeden oluşmaktadır. Söz konusu ifadeler altı noktalı Likert ölçeği ile derecelendirilmiştir. Litratürde örgütsel adalet değişkeni; dağıtım adaleti, etkileşim adaleti ve prosedür adaleti olmak üzere üç boyutta ele alınır. Bu çalışmada BT çalışanlarının işe yabancılaşması kapsamında daha önce yapılan çalışmalar incelendiğinde, prosedür adaletinin etkisine yönelik doğrudan ve dolaylı etkilerin analiz edilmesinin uygun olduğuna karar verilmiştir. Bu kapsamda, örgütsel adaletin sadece prosedür adaleti boyutu araştırma modeline dahil edilmiştir. Prosedür adaletini ölçmek için Colquitt (2001) tarafından geliştirilen ölçek kullanılmıştır. Ölçek yedi maddeden oluşmaktadır. İş özerkliği ölçekleği ise, Lim'in (2008) çalışmasından alınmıştır ve dört ifadeden oluşmaktadır. BT çalışanlarının algıladıkları rol çatışmasını ölçmek için Rizzo, House ve Lirtzman (1970) tarafından geliştirilen ve sekiz ifadeden oluşan ölçek esas alınmıştır. Prosedür adaleti, iş özerkliği ve rol çatışması ifadeleri yedi noktalı Likert ölçeğine göre derecelendirilmiştir.

Teknoloji kullanımı konusunda uzman olan BT çalışanlarına online anket ile ulaşmanın daha elverişli olacağı ve anketin katılımcılar tarafından daha kolay cevaplanacağı düşünülerek anket formu internet aracılığıyla tasarlanmıştır. BT çalışanlarının mail adreslerine ulaşmak için öncelikle şirketlerin web sayfaları kullanılmış, ayrıca iş dünyasındaki kişilerin birbirleri ile iletişim kurmasını sağlayan profeyonel sosyal paylaşım platformu LinkedIn'den yararlanılmıştır. Söz konusun platform üzerinden potansiyel katılımcılara anket ve çalışmanın amacı hakkında bilgi paylaşılmıştır. Elde edilen veriler analize uygunluk açısından gözden geçirilmiş ve toplam olarak 172 kullanılabilir anketten elde edilen veriler ile analizler yapilmıştır. 


\subsection{Veri Analizi ve Bulgular}

Katılımcıların demografik özellikleri ile ilgili tanımlayıcı istatistikler incelendiğinde; cinsiyet değişkeni açısından örneklemin yarıdan fazlası erkek (\% 66,9) katılımcılardan oluşmaktadır. Eğitim düzeyleri açısından çoğunluğun lisans (\% 68), geri kalan bölümün lisansüstü (\%32) derecesine sahip olduğu görülmüştür. İş sorumluluklarına göre, katılımcıların yarıya yakını programcı (\%45), yazılımcı (\%37) ve kalan kısmı ă̆ yöneticisi (\%18) olduklarını belirtmişlerdir.

Araştırma hipotezlerinin yapısal denklem modellemesi ile test edilmesi amacıyla üç aşamadan oluşan bir süreç izlenmiştir. İlk aşamada yapılan ölçümlerin psikometrik uygunluklarını değerlendirmek üzere Doğrulayıcı Faktör Analizi (DFA) yapılmıştır. Bu şekilde kullanılan ölçeklerin literatürde yer alan ve daha önce kullanılmış boyutlar ile uyumlu olup olmadığı istatistiksel olarak incelenmiştir. DFA sonuçları Tablo 1'de sunulmuştur.

İkinci aşamada yapılar arasındaki ilişkiler geçerlilik ve güvenirlik analizleri yapılarak incelenmiştir. Bu kapsamda iç tutarlılık güvenirliği (Cronbach Alfa ve $\mathrm{CR}=$ Composite Reliability değerleri incelenerek), birleşme geçerliği (faktör yükleri ve $\mathrm{AVE}=$ Average Variance Extracted değerleri incelenerek) ve ayrışma geçerliği Fornell ve Larcker (1981) tarafından önerilen kriter ve Henseler ve diğerleri (2015) tarafından önerilen HTMT kriteri kullanılarak analiz edilmiştir. Fornell ve Larcker kriteri; araştırmada yer alan yapıların açıklanan ortalama varyans (AVE) değerlerinin karekökünün, söz konusu yapılar arasındaki korelasyonlardan yüksek olması gerekliliğidir. Analiz bulguları sırasıyla Tablo 2, 3 ve 4 'te sunulmuştur.

Hair ve diğerleri (2014); DFA sonucu elde edilen faktör yüklerinin $\geq 0.70$ olması gerektiğini, ancak faktör yükleri 0.40 ile 0.70 değerleri arasında yer alıyorsa CR ve AVE değerlerinin gözden geçirilmesini, bu değerler eşik değerleri sağlamıyorsa modelden çıkarılması gerektiğini önermektedir. Bu kapsamda yapılan analiz değerlendirmeleri sonucu bahsedilen koşulu sağlamayan ifadeler modelden çıkarılmıştır. Dolayısıyla ROLCAT4, ADALET7, KENYAB7 ve YABGUC1, isimli ifadeler analiz dışı bırakılmıştır. 
Tablo 1. DFA Sonuçları

\begin{tabular}{|c|c|c|c|c|c|}
\hline Değişken & İfade & Faktör Yükü & $\begin{array}{l}\text { Cronbach } \\
\text { Alfa }\end{array}$ & CR & AVE \\
\hline \multirow{6}{*}{ Prosedür Adaleti } & ADALET1 & 0.730 & \multirow{6}{*}{0.854} & \multirow{6}{*}{0.892} & \multirow{6}{*}{0.579} \\
\hline & ADALET2 & 0.794 & & & \\
\hline & ADALET3 & 0.814 & & & \\
\hline & ADALET4 & 0.794 & & & \\
\hline & ADALET5 & 0.732 & & & \\
\hline & ADALET6 & 0.696 & & & \\
\hline \multirow{4}{*}{ İş Özerkliği } & İŞÖZ1 & 0.931 & \multirow{4}{*}{0.870} & \multirow{4}{*}{0.903} & \multirow{4}{*}{0.704} \\
\hline & İŞÖZ2 & 0.847 & & & \\
\hline & İŞÖZ3 & 0.902 & & & \\
\hline & İŞÖZ4 & 0.646 & & & \\
\hline \multirow{7}{*}{ Rol Çatışması } & ROLÇAT1 & 0.678 & \multirow{7}{*}{0.851} & \multirow{7}{*}{0.888} & \multirow{7}{*}{0.534} \\
\hline & ROLÇAT2 & 0.600 & & & \\
\hline & ROLÇAT3 & 0.735 & & & \\
\hline & ROLÇAT5 & 0.662 & & & \\
\hline & ROLÇAT6 & 0.742 & & & \\
\hline & ROLÇAT7 & 0.891 & & & \\
\hline & ROLÇAT8 & 0.769 & & & \\
\hline \multirow{4}{*}{$\begin{array}{l}\text { (İşe Yabancilaşma) } \\
\text { Anlamsızlık }\end{array}$} & YABAN1 & 0.730 & \multirow{4}{*}{0.820} & \multirow{4}{*}{0.879} & \multirow{4}{*}{0.646} \\
\hline & YABAN2 & 0.843 & & & \\
\hline & YABAN3 & 0.807 & & & \\
\hline & YABAN4 & 0.830 & & & \\
\hline \multirow{5}{*}{$\begin{array}{l}\text { (İşe Yabancilaşma) } \\
\text { Güçsüzlük }\end{array}$} & YABGUC2 & 0.705 & \multirow{5}{*}{0.789} & \multirow{5}{*}{0.855} & \multirow{5}{*}{0.546} \\
\hline & YABGUC3 & 0.745 & & & \\
\hline & YABGUC4 & 0.820 & & & \\
\hline & YABGUC5 & 0.824 & & & \\
\hline & YABGUC6 & 0.571 & & & \\
\hline \multirow{6}{*}{$\begin{array}{l}\text { (İşe Yabancılaşma) } \\
\text { Kendine Yabancılaşma }\end{array}$} & KENYAB1 & 0.849 & \multirow{6}{*}{0.853} & \multirow{6}{*}{0.890} & \multirow{6}{*}{0.579} \\
\hline & KENYAB2 & 0.646 & & & \\
\hline & KENYAB3 & $\begin{array}{r} \\
\end{array}$ & & & \\
\hline & KENYAB4 & 0.756 & & & \\
\hline & KENYAB5 & 0.845 & & & \\
\hline & KENYAB6 & 0.821 & & & \\
\hline
\end{tabular}

DFA analizi sonucu elde edilen yapıların, Cronbach Alfa katsayılarının 0.789 ve 0.870 arasında yer aldığı; CR katsayılarının ise 0.855 ve 0.903 değerleri arasında gerçekleştiği ve eşik değer olan 0.70'den büyük oldukları görülmüştür. Böylece iç tutarlılık güvenirliğinin sağlandığı söylenebilir. Tablo 1'de görüldüğü gibi her bir boyutta yer alan ifadelerin faktör yükleri 0.571 ile 0.931 değerleri arasında dağılmaktadır. Yapıların AVE değerlerinin 0.534 ile 0.704 arasında yer alması ve eşik değer olan 0.50 'den büyük olması dikkate alındığında birleşme geçerliğinin sağlandığı anlaşılmıştır. 
Sunulan modelin ayrışma geçerliğinin belirlenmesinde, Fornell ve Larcker (1981) ve Henseler ve diğerleri (2015) tarafından önerilen kriterler dikkate alınmıştır. Modelde yer alan yapıların AVE değerlerinin karekökleri, modelde yer alan yapılar arasındaki korelasyonlardan yüksek olduğu için (Tablo 2) Fornell ve Larcker kriteri sağlandığı anlaşılmıştır.

Tablo 2. Ayrışma Geçerliliği Analizi Bulguları

\begin{tabular}{|c|c|c|c|c|c|c|}
\hline & $\begin{array}{c}\text { İş } \\
\text { Özerkliği }\end{array}$ & Anlamsızlık & Güçsüzlük & $\begin{array}{c}\text { Prosedür } \\
\text { Adaleti }\end{array}$ & $\begin{array}{c}\text { Rol } \\
\text { Çatışması }\end{array}$ & $\begin{array}{c}\text { Kendine } \\
\text { Yaban. }\end{array}$ \\
\hline İş Özerkliği & $\mathbf{0 . 8 3 9}$ & & & & & \\
\hline Anlamsızlık & -0.381 & $\mathbf{0 . 8 0 4}$ & & & & \\
\hline Güçüuzlük & -0.491 & 0.551 & $\mathbf{0 . 7 3 9}$ & & & \\
\hline Prosedür Adaleti & 0.467 & -0.459 & -0.718 & $\mathbf{0 . 7 6 1}$ & & \\
\hline Rol Çatışması & -0.245 & 0.443 & 0.437 & -0.481 & $\mathbf{0 . 7 3 0}$ & \\
\hline $\begin{array}{c}\text { Kendine } \\
\text { Yabancılaşma }\end{array}$ & -0.372 & 0.579 & 0.652 & -0.556 & 0.449 & $\mathbf{0 . 7 6 1}$ \\
\hline
\end{tabular}

Tablo 2'de sunulan analiz bulguları ilgili kritere göre yapılan hesaplama sonuçlarını göstermektedir. Tabloda koyu renk ile belirginleştirilmiş rakamlar yapıların AVE değerlerinin karekök değerleridir. Bu değerler yapıların korelasyon katsayılarından daha yüksektir.

Henseler ve diğerlerin (2015) öne sürdüğü HTMT kriteri; modelde yer alan tüm yapılara ait ifadelerin korelasyonlarının ortalamasının ifadelerin geometrik ortalamalarına oranlarını ifade eder. HTMT değerinin, teorik olarak birbirine yakın kavramlarda 0.90'nın, birbirine uzak kavramlarda ise $0.85^{\prime}$ in altında olması gerektiği öne sürülmüştür. Tablo 3'te görüldüğü üzere; sunulan modelin HTMT değerleri eşik değerlerin altındadır.

Tablo 3. Ayrışma Geçerliliği Sonuçları (HTMT Kriteri)

\begin{tabular}{|c|c|c|c|c|c|c|}
\hline & $\begin{array}{c}\text { İş } \\
\text { Özerkliği }\end{array}$ & Anlamsızlık & Güçsüzlük & $\begin{array}{c}\text { Prosedür } \\
\text { Adaleti }\end{array}$ & $\begin{array}{c}\text { Rol } \\
\text { Çatışması }\end{array}$ & $\begin{array}{c}\text { Kendine } \\
\text { Yaban. }\end{array}$ \\
\hline İş Özerkliği & & & & & & \\
\hline Anlamsızlık & 0.381 & & & & & \\
\hline Güçsüzlük & 0.577 & 0.678 & & & & \\
\hline Prosedür Adaleti & 0.483 & 0.519 & 0.856 & & & \\
\hline Rol Çatışması & 0.272 & 0.507 & 0.516 & 0.565 & & \\
\hline $\begin{array}{c}\text { Kendine } \\
\text { Yabancılaşma }\end{array}$ & 0.389 & 0.690 & 0.744 & 0.620 & 0.492 & \\
\hline
\end{tabular}


Tablo 2 ve 3 'te ayrışma geçerliğine ilişkin literatürde sıklıkla kullanılan her iki kriterin sağlanmış olması ayrışma geçerliğinin sağlandığına işaret etmektedir. Analiz sürecinin üçüncü aşamasında sunulan hipotezlerin yapısal eşitlik modellemesine geçilmiştir. Şekil 2'de yapısal eşitlik modeli ve analize ilişkin katsayılar gösterilmiştir.

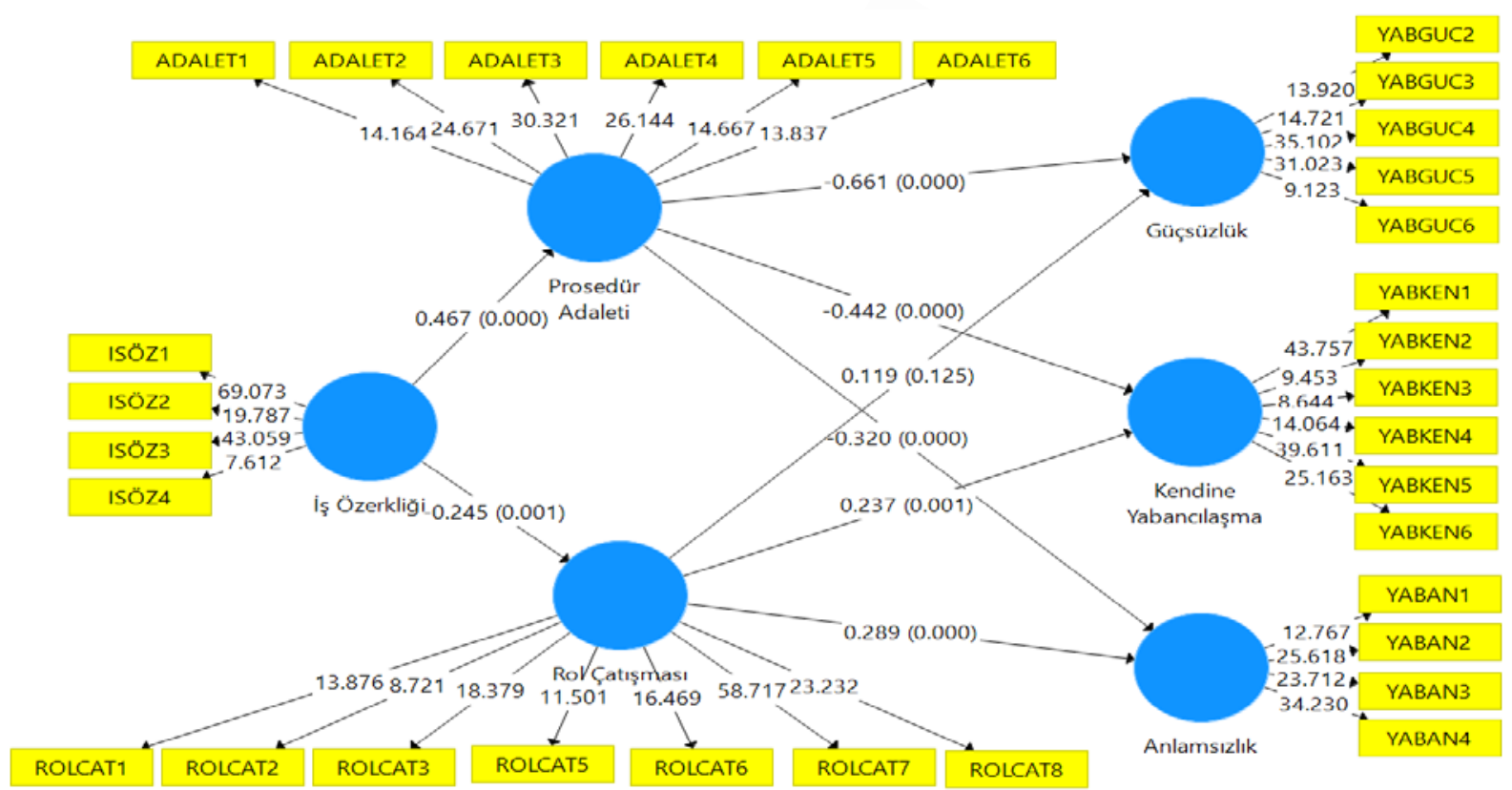

Şekil 2. Yapısal Eşitlik Model Testi Sonuçları

Yapısal eşitlik modeli analizinde kısmi en küçük kareler yol analizi (PLS-SEM) kullanılmıştır, eldeki veriler Smart PLS 3.2.8 programı ile analiz edilmiştir (Ringle ve diğ. 2015). Analiz sürecinde doğrusallık, regresyon, yol katsayıları ve yapılar arasındaki etki büyüklüğü (f² $)$ hesaplaması için PLS algortiması kullanılmıştır. PLS yol katsayılarının anlamlılık değerlerini incelemek üzere yeniden örnekleme (bootstrapping) ve örneklemden 5000 alt örneklem seçilerek $t$ değerleri hesaplanmıştır. Ayrıca Blindfolding analizi kullanılarak tahmin gücü $\left(\mathrm{Q}^{2}\right)$ incelenmiştir.

Analizler sonucunda hesaplanan $\mathrm{R}^{2}, \mathrm{f}^{2}, \mathrm{Q}^{2}$ ve VIF değerleri Tablo 4'te sunulmuştur. 
Tablo 4. Araştırma Modeli Sonuçları

\begin{tabular}{|c|c|c|c|c|c|}
\hline Değişkenler & & $\mathbf{R}^{2}$ & $\mathbf{f}^{2}$ & $\mathrm{Q}^{2}$ & VIF \\
\hline İş Özerkliği & Prosedür Adaleti & 0.218 & 0.279 & 0.123 & 1.000 \\
\hline & Rol Çatışması & 0.060 & 0.064 & 0.030 & 1.000 \\
\hline Prosedür Adaleti & \multirow[b]{2}{*}{ Güçsüzlük } & \multirow[b]{2}{*}{0.527} & 0.709 & \multirow[b]{2}{*}{0.272} & 1.300 \\
\hline Rol Çatışması & & & 0.023 & & 1.300 \\
\hline Prosedür Adaleti & \multirow[b]{2}{*}{ Kendine Yaban. } & \multirow[b]{2}{*}{0.352} & 0.231 & \multirow[b]{2}{*}{0.187} & 1.300 \\
\hline Rol Çatışması & & & 0.067 & & 1.300 \\
\hline Prosedür Adaleti & \multirow[b]{2}{*}{ Anlamsizlık } & \multirow{2}{*}{0.275} & 0.109 & \multirow[t]{2}{*}{0.166} & 1.300 \\
\hline Rol Çatışması & & & 0.089 & & 1.300 \\
\hline
\end{tabular}

Yapılar arasında doğrusallık problemi olmaması için Hair ve diğerleri (2014) varyans şişirme faktörünün (VIF) 5' in altında olmasını tavsiye etmektedir. Tablo 4'te yapılara ait VIF değerlerinin eşik değerin altında olması doğrusallık problemi olmadığını göstermektedir. $\mathrm{R}^{2}$ değerleri; prosedür adaletinin \%22, rol çatışmasının \%0,6 oranında, güçsüzlük algısının \%52, kendine yabancılaşmanın \%35 ve anlamsızlık algısının \%27 oranında açıklandı̆̆ını belirtmektedir.

Cohen'e (1988) göre etki büyüklüğü katsayısı $\left(\mathfrak{f}^{2}\right) \geq 0.02$ olması düşük, $\geq 0.15$ olması orta ve $\geq 0.35$ olması yüksek etkiyi göstermektedir. Tablo 5'te yer alan değerleri incelendiğinde iş özerkliği prosedür adaleti üzerinde orta, rol çatışması üzerinde düşük etkiye sahiptir. Güçsüzlük üzerinde; prosedür adaleti orta, rol çatışması düşük etkiye sahiptir. İşe yabancılaşmanın diğer iki alt boyutu olan anlamsızlık ve kendine yabancılaşma üzerinde prosedür adaleti orta ve rol çatışması düşük etkiye sahiptir.

Modelin tahmin gücü katsayıları $\mathrm{Q}^{2}>0$ ise modelin endojen değişkenleri tahmin gücüne sahiptir (Hair ve diğgerleri, 2014). Tablo 4’te yer alan ilgili katsayıların sıfırdan büyük olması nedeni ile iş özerkliği, rol çatışması ve prosedür adaleti değişkenlerinin modelin bağımlı değişkenleri olan işe yabancılaşma alt boyutlarını tahmin gücüne sahip olduğu söylenebilir.

Analiz edilen modelde yer alan doğrudan etkilere ilişkin $\beta$, standart sapma, $t$ değeri ve anlamlılık bulguları Tablo 5'te sunulmuştur. İş özerkliği prosedür adaletini $(\beta=0.467, p<0.001)$ pozitif yönde, rol çatışmasını ise $(\beta=-0.245, p<0.001)$ negatif 
yönde etkilemektedir. Bu bulgular 1şı̆̆ında modelin $\mathrm{H}_{1}$ ve $\mathrm{H}_{2}$ hipotezleri kabul edilmiştir.

Tablo 5. Araştırma Modeli Doğrudan Etki Katsayıları

\begin{tabular}{|c|c|c|c|c|c|c|}
\hline \multicolumn{2}{|r|}{ Değişkenler } & 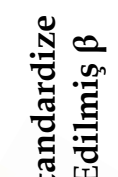 & 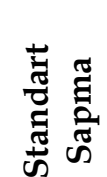 & 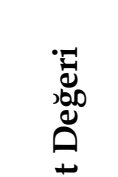 & 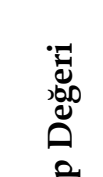 & $\begin{array}{l}\text { हี } \\
\text { ڤే }\end{array}$ \\
\hline $\mathrm{H}_{1}$ & İş Özerkliği -> Prosedür Adaleti & 0.467 & 0.062 & 7.571 & 0.000 & $\mathrm{~K}$ \\
\hline $\mathrm{H}_{2}$ & İş Özerkliği -> Rol Çatışması & -0.245 & 0.077 & 3.197 & 0.000 & $\mathbf{K}$ \\
\hline $\mathrm{H}_{3 \mathrm{a}}$ & Prosedür Adaleti -> Güçsüzlük & -0.661 & 0.062 & 10.744 & 0.000 & $\mathbf{K}$ \\
\hline $\mathrm{H}_{3 \mathrm{~b}}$ & 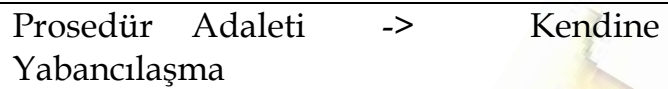 & -0.442 & 0.056 & 7.875 & 0.000 & $\mathbf{K}$ \\
\hline $\mathrm{H}_{3 \mathrm{c}}$ & Prosedür Adaleti -> Anlamsızlık & -0.320 & 0.081 & 3.961 & 0.000 & $\mathbf{K}$ \\
\hline $\mathrm{H}_{4 \mathrm{a}}$ & Rol Çatışması $\quad$-> Güçsüzlük & 0.119 & 0.078 & 1.536 & 0.125 & $\mathbf{R}$ \\
\hline $\mathrm{H}_{4 \mathrm{~b}}$ & Rol Çatışması -> Kendine Yabancılaşma & 0.237 & 0.072 & 3.289 & 0.001 & $\mathbf{K}$ \\
\hline $\mathrm{H}_{4 \mathrm{c}}$ & Rol Çatışması -> Anlamsızlık & 0.289 & 0.083 & 3.506 & 0.000 & $\mathbf{K}$ \\
\hline
\end{tabular}

Prosedür adaleti, işe yabancılaşmanın alt boyutlarından güçsüzlüğü ( $\beta=$ $0.661, \mathrm{p}<0.001)$, kendine yabancılaşmayı $(\beta=-0.442, \mathrm{p}<0.001)$ ve anlamsızlığ1 $(\beta=-$ 0.320, p<0.001) negatif yönde etkilemektedir. Modelin $\mathrm{H}_{3 a}, \mathrm{H}_{3 b}$ ve $\mathrm{H}_{3 c}$ hipotezleri kabul edilmiştir.

Rol çatışması, işe yabancılaşmanın alt boyutlarından güçsüzlüğü anlamlılık ( $p>0.001)$ değeri uygun olmadığı için açıklamamakta, kendine yabancılaşmayı ( $\beta=$ 0.237, $\mathrm{p}<0.001)$ ve anlamsızlı̆̆1 $(\beta=0.289, \quad \mathrm{p}<0.001)$ pozitif yönde etkilemektedir. Modelin $\mathrm{H}_{4 a}$ hipotezi red edilmiş, $\mathrm{H}_{4 \mathrm{~b}}$ ve $\mathrm{H}_{4 \mathrm{c}}$ hipotezleri ise desteklenmiştir.

Analiz edilen modelde yer alan dolaylı etkilere ilişkin $\beta$, standart sapma, $t$ değeri ve anlamlılık bulguları Tablo 6' da sunulmuştur. 
Tablo 6. Araştırma Modeli Dolaylı Etki Katsayıları

\begin{tabular}{|c|c|c|c|c|c|c|}
\hline & Değişkenler & 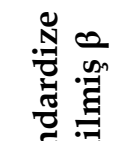 & 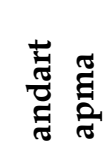 & 苞 & صَّ & \\
\hline $\mathrm{H}_{5 \mathrm{a}}$ & İş özerkliği -> Prosedür Adaleti -> Güçsüzlük & -0.309 & 0.055 & 5.655 & 0.000 & $\mathbf{K}$ \\
\hline $\mathrm{H}_{5 \mathrm{~b}}$ & $\begin{array}{l}\text { İş özerkliği -> Prosedür Adaleti -> } \\
\text { Yaban. }\end{array}$ & -0.206 & 0.042 & 4.966 & 0.000 & K \\
\hline $\mathrm{H}_{5 \mathrm{c}}$ & İş özerkliğgi -> Prosedür Adaleti -> Anlamsızlık & -0.150 & 0.047 & 3.191 & 0.001 & K \\
\hline $\mathrm{H}_{6 \mathrm{a}}$ & İş özerkliği -> Rol Çatışması -> Güçsüzlük & -0.029 & 0.026 & 1.144 & 0.252 & $\mathbf{R}$ \\
\hline $\mathrm{H}_{6 \mathrm{~b}}$ & İş özerkliği -> Rol Çatışması -> Kendine Yaban. & -0.058 & 0.031 & 1.880 & 0.060 & $\mathbf{R}$ \\
\hline $\mathrm{H}_{6 c}$ & İş özerkliği -> Rol Çatışması -> Anlamsızlık & -0.071 & 0.037 & 1.909 & 0.056 & $\mathbf{R}$ \\
\hline
\end{tabular}

Tablo 6'da sunulan bulgulara göre; iş özerkliği prosedür adaleti üzerinden güçsüzlük algısını $(\beta=-0.309, \quad p<0.001)$, kendine yabancılaşma algısını $(\beta=-0.206$, $p<0.001)$ ve anlamsızlık alg1sını $(\beta=-0.150, p<0.001)$ dolaylı olarak etkilemektedir. Anlamlılık (p) değerlerine göre $\mathrm{H}_{5 \mathrm{a}} \mathrm{H}_{5 \mathrm{~b} \text { ve }} \mathrm{H}_{5 \mathrm{c}}$ hipotezleri desteklenmiştir.

Dolaylı etkilerden, iş özerkliği rol çatışması üzerinden güçsüzlük algısını, kendine yabancılaşma algısını ve anlamsızlık algısını dolaylı olarak etkilememektedir. $\mathrm{H}_{6 \mathrm{a}} \mathrm{H}_{6 \mathrm{~b}}$ ve $\mathrm{H}_{6 c}$ hipotezlerinin anlamlılık ( $\left.\mathrm{p}>0.001\right)$ değerleri uygun olmadığı için her üç hipotezde desteklenmemiştir.

\section{TARTIŞMA ve SONUÇ}

Bu çalışmada; İş Talepleri ve İş Kaynakları Modeli kapsamında, iş görenlerin işe yabancılaşma algıları bağımlı değişken olmak üzere, iş özerkliği, rol çatışması ve prosedür adaleti değişkenleri arasındaki ilişkiler analiz edilmiştir. Bu amaçla yapısal denklem modeli kullanılarak test edilen araştırma modelinin sonuçları, iş özerkliği, rol çatışması ve prosedür adaleti değişkenlerinin çalışanların işe yabancılaşma algısını tahmin gücüne sahip olduğunu göstermektedir.

İşe yabancılaşmanın alt boyutlarından biri olan güçsüzlük, çalışanın yaptı̆̆ı iş üzerinde kontrol ve özgürlük hakkının olmayışıdır (Shepard, 1971, s.3-14). Benzer şekilde, yabancılaşmanın diğer boyutu olan anlamsızlık boyutu da çalışanın, üretim sürecine katkı ve kontrol açısından çok az özerkliğe sahip olduğu inancını yansıtır (Mottaz, 1981, ss. 516-517). Çalışmanın bulguları, iş özerkliğinin; prosedür adaleti 
üzerinden güçsüzlük, kendine yabancılaşma ve anlamsızlık algılarını dolaylı olarak etkilediğini göstermektedir. İş Talep-Kaynak Modeli çerçevesinde değerlendirildiğinde, iş özerkliği çalışanların motivasyonunu artıran kaynaklar arasında ele alınabilir. Bu kurama göre, çalışanlara işlerini yürütmeleri konusunda gerekli özerkliğin tanınması durumunda, işlerine karşı olumsuz tutumlar geliştirmeleri önlenebilir. Bu durumda çalışanlardan beklenen talepler fazla bile olsa, çalışanlar bu talepleri kontrol edebileceklerine ilişkin bir inanç geliştirebilirler. Yetki ve sorumlulukların özgürce kullanmasına izin verilen bir çalışma ortamında prosedürlerin ise daha adil olduğu algısının oluşması beklenir (Demereouti ve diğerleri, 2001). Kısacası modelde kaynak olan iş özerkliği, işyerindeki prosedürlerin adil olarak uygulandığı algısını olumlu yönde etkilemektedir. Benzer şekilde çeşitli araştırmalarda, iş özerkliği, bir iş kaynağı olarak değerlendirilmiş ve bu kaynakların işe karşı geliştirilen tutumları belirlemedeki etkileri, İş Talep-Kaynak Modeli (Demerouti, Bakker, Nachreiner ve Schaufeli, 2001; Bakker ve Demerouti, 2007) çerçevesinde incelenmiştir. Diğer taraftan, işe ilişkin taleplerin yüksek ve işe ilişkin kaynakların sınırlı olması durumunda, çalışanlar olumsuz tutumlar geliştirebilmekte ve bu noktada işlerine karşı yabancılaşabilmektedirler. Benzer şekilde literatürdeki çalışmalar, iş özerkliği sunmayan çalışma ortamlarında adalet algısının olumsuz etkileneceği bu durumunda işe yabancılaşma ile sonuçlanabileceğini ileri sürmüşlerdir (Camgöz ve Ekmekci, 2017). Yine, Sookoo, (2014); Merkhe (2015); Howard ve Cordes (2010); Zengin ve Kaygın (2016) çalışmalarında, prosedür adaletinin işe yabancılaşma üzerinde negatif yönde bir etki yarattı̆̆ııı belirlemişlerdir.

Çalışmada elde edilen bir diğer bulgu, rol çatışmasının işe yabancılaşmayı pozitif yönde etkilemesidir. İşe yabancılaşmanın alt boyutlarından anlamsızlık, çalışanların yaptıkları işin, bağlı oldukları örgütün amaçlarını ve bu ikisinin birbiriyle olan ilgisini kavrayamamasıdır (Kanungo, 1982b, s.26). Dolayısıyla çalışanın kendinden beklenen roller ile yetkinlikleri ve uzmanlığı doğrultusunda olması gerektiğine inandığı rol arasında yaşanan bir çatışma, çalışanı işten uzaklaştırabilir. Talep- kaynak modelinde göre, talep kategorisinde yer alan rol çatışması (Demerouti ve Bakker, 2011), hem yöneticiler hem de çalışanlar için önemli 
bir yabancılaşma kaynağıdır (Arslan ve Üngüren, 2017). Benzer şekilde, Michaels ve diğerleri (1996); Agarwal (1993, s. 732) ve Korman ve diğ. (1981) rol çatışmasının işe yabancılaşmayı arttırdı̆̆ını belirlemişlerdir.

Araştırma kapsamında ele alınan bilgi teknolojileri sektörü, tüm gelişmiş ve gelişmekte olan ülkeler için "stratejik sektör" olarak tanımlanmaktadır. Sektörün özellikleri dikkate alındığında, gittikçe büyüyen bu sektörde nitelikli eleman açığı ciddi bir sorun teşkil etmektedir. Sektörün büyümesi ile doğrudan ilişkili olan nitelikli elemanların yetiştirilip istihdam edilmesi son derece önemlidir. Bunun yanı sıra sektörde hali hazırda istihdam edilen çalışanların ise iş ortamı tasarımından kaynaklanan çeşitli sorunlarla karşılaştıkları gözlenmektedir. Bu sorunlar nedeniyle BT çalışanları iş ortamlarında ihtiyaç duydukları motivasyonu ve tatmini hissedememektedir. $\mathrm{Bu}$ sorunların en başında çalışanların yeterince özerk olmadıklarına yönelik inançları gelmektedir. Yenilikçiliğin ve yaratıcılığın son derece önemli olduğu bilgi teknolojileri sektöründe, çalışanların yeni fikirler üretme ve bunları projelendirip uygulama konusunda özerk oldukları inancına ihtiyaçları vardır. Dolayısıyla BT çalışanları, iş ortamlarında özerk olmayı ve spesifik olarak profesyonel gelişimleri ile ilgili kararlarda söz sahibi olmayı önemsemektedir (Kinnear ve Sutherland, 2000). Bununla beraber BT çalışanları, diğer sektörlerin çalışanları gibi, belirlenen politika ve alınan kararların nedenleri hakkındaki açıklamalara, bu kararların verilmesinde kullanılan veri ve bilgilerin doğruluğuna ve performans değerlendirme kriterlerinin herkes için açık olmasını beklerler. $\mathrm{Bu}$ beklentilerin ve ihtiyaçların giderilmesi, iş yerindeki örgütsel adalete ilişkin algıları doğrudan etkiler. Geçmiş çalışmalar, kurumsal sistem ve özellikle prosedür adaletinin, bilgi çalışanları için büyük önem taşıdığına işaret etmektedir (Kim ve Mauborgne, 1997). Kim ve Mauborgne (1997), çalışan bağlılı̆̆ının en önemli belirleyicisinin örgüte duyulan güven olduğunu öne sürmektedir. Örgütsel adalet algısı bu güveni oluşturmada son derece etkilidir. Benzer şekilde çalışanların yaşadıkları rol çatışması, BT çalışanlarının yabancılaşmasında etkilidir. Aldıkları eğitim, nitelik ve beceriler ile örtüşmeyen görev dağılımları ve yine bu özelliklerin değerlendirilmesinde gerekli özerkliği sunmayan çalışma ortamları, sektör çalışanlarında rol çatışmasına ve devamında işlerine yabancılaşmalarına neden 
olmaktadır. Dolayısıyla, sektör çalışanları arasındaki çatışmayı önlemek ve rolleri belirgin hale getirmek için mesleki eğitim, uzmanlık ve becerilere göre görev tanımı ve dağılımı yapmak gereklidir.

Sonuç olarak, ülke ekonomilerinin gelişiminde lokomotif görevi gören bilgi teknolojileri sektörünün gelişimi ve büyümesi, bu sektörde faaliyetlerini yürüten firmaların yatırımlarının karşılığını alabilmeleri, sektör çalışanlarının motivasyonun sağlanmasıyla doğrudan ilişkilidir. Bu kapsamda sektör çalışanlarının kariyer gelişimleri ve uzmanlıklarını sergileme konusunda çeşitli destek programları ve teşviklerin geliştirilmesi için devlet ve özel sektörün eşgüdümlü çalışması gereklidir. Özellikle firma yöneticilerinin hiçbir maddi servetin insan kaynağından daha önemli olmadığı anlayışını benimsemiş olmaları önemlidir. Çalışan odaklı yöneticilik anlayışı, verimliliği ve üretkenliği artırmada her zaman etkilidir.

Çalışmada, örgütsel adalet değişkeninin yalnızca prosedür adaleti boyutunu ele alınması çalışmanın bir kısıtıdır. Sadece prosedür adaleti boyutunun dikkate alınmasının nedeni, bu adalet türünün genellikle çatışma durumunu çözme, karar verme ve kaynakların dağıtımı ile ilgili süreçlerin doğru yöntemler ile yönetilmesini sorgulamasıdır (Folger ve Cropanzano, 1998, s.26). Ayrıca çalışmanın araştırma sorusu ile doğrudan bağlantılıdır. İleride yürütülecek çalışmalarda örgütsel adalet değişkeninin tüm boyutlarını ele alan çalışmalar, sektördeki sorunlar hakkında derinlemesine bakış açıları sağlamak için yarar sağlayabilir. Çalışma, İstanbul'da faaliyetlerini sürdüren bilgi teknolojileri sektörü çalışanları üzerinde gerçekleştirilmiştir. Buna ek olarak araştırmanın sonuçları çalışmanın örneklemini oluşturan 172 BT çalışanının görüşleri ile sınırlıdır. Bu kapsamada bir pilot çalışma olarak değerlendirilebilir. Dolayısıyla değişkenler arasındaki ilişkilerin daha geniş örneklemler ile analiz edilmesi ve farklı sektör çalışanlarından veri toplanarak karşılaştırmalar yapılması muhtemeldir. 


\section{KAYNAKÇA}

Agarwal, S. (1993). Influence of Formalization on Role Stress, Organizational Commitment, and Work Alienation of Salespersons: A Cross-National Comparative Study. Journal of International Business Studies, 24(4), 715-739.

Agarwal, U. A. (2014). Linking Justice, Trust and Innovative Work Behaviour to Work Engagement. Personnel Review, 43(1).

Aiken, M., \& Hage, J. (1968). Organizational Interdependence and Intra-Organizational Structure. American Sociological Review, 33(6), 912-930.

Arslan, S., \& Üngüren, E. (2017). Rol Çatışması ve Rol Belirsizliğinin Örgütsel Yabancılaşmaya Etkisi: Alanya Belediyesi'nde Bir Araştırma. Çağdaş Yerel Yönetimler Dergisi, 26(4), 43-84.

Atay S. E. \& Gerçek M. (2017). Algılanan Rol Belirsizliğinin İşe Yabancılaşma Üzerindeki Etkisinin ve Demografik Değişkenlere Göre Farklılıklarının İncelenmesi. Ordu Üniversitesi Sosyal Bilimler Araştırmaları Dergisi, 7(2), 321-332.

Atilla Bal, E. (2008). Self-Efficacy, Contextual Factors and Well-Being: The Impact of Work Engagement. Unpublished Doctoral Thesis, Social Sciences Institute, Department of Organizational Behavior, Marmara University, Istanbul, Turkey.

Bakker, A. B. (2011). An Evidence-Based Model of Work Engagement. Current directions in psychological science, 20(4), 265-269.

Bakker, A. B. \& Demerouti, E. (2007). The Job Demands-Resources Model: State of The Art. Journal of Managerial Psychology, 22(3), 309-328.

Başoda, A. (2017). İşe Tutkunluk: Kavramsal Açıdan Bir İnceleme. Tarihin Peşinde, 9(17), 71-95.

Behrman, D.N. \& Perreault, W.D. (1984). A Role Stress Model of The Performance and Satisfaction of Industrials Salespersons. Journal of Marketing, 48 (Fall), 9.

Berardi, F. B. (2010). The Soul at Work: From Alienation to Autonomy. Los Angeles CA: Semiotext(e), p. 229.

Blauner, R. (1964). Alienation and Fredoom: The Factory Worker and His Industry. Chicago: The University of Chicago Press.

Blodgett, J. G., Hill, D. J., \& Tax, S. S. (1997). The Effects of Distributive, Procedural, and Interactional Justice on Post Complaint Behavior. Journal of Retailing, 73, 185-210.

Bryant, R. M., \& Constantine, M. G. (2006). Multiple Role Balance, Job Satisfaction, and Life Satisfaction in Women School Counselors", Professional School Counseling, 9(4), 265-271.

Camgöz, S. M., Ekmekci, Ö. T., \& Karapınar, P. B. (2017). Örgütsel Sinizmin İş Yükü, Algılanan Adalet ve Kontrol Açısından İncelenmesi. İşletme Araştırmaları Dergisi, 9(3), 40-59.

Ceylan, A., \& Sulu, S. (2010). Work Alienation as A Mediator of The Relationship of Procedural Injustice to Job Stress. South East European Journal of Economics and Business, 5(2), 65-74.

Chiaburu, D. S., Thundiyil, T., \& Wang, J. (2014). Alienation and Its Correlates: A META-Analysis. European Management Journal, 32(1), 24-36. 
Chilton, M. A., Hardgrave, B. C., \& Armstrong, D. J. (2010). Performance and Strain Levels of It Workers Engaged in Rapidly Changing Environments: A Person-Job Fit Perspective. ACM SIGMIS Database: the DATABASE for Advances in Information Systems, 41(1), 8-35.

Cohen, J. (1988). Statistical Power Analysis for the Behavioral Sciences. Lawrence Erlbaum, Mahwah. NJ

Coelho F., Augusto M., \& Lages L. F., (2011). Contextual Factors and the Creativity of Frontline Employees: The Mediating Effects of Role Stress and Intrinsic Motivation, Journal of Retailing, 87(1).

Colquitt, J. A. (2001). On The Dimensionality Of Organizational Justice: A Construct Validation Of A Measure. Journal of Applied Psychology, 86, 386-400.

Conway, E., Monks, K., Fu, N., Alfes, K., \& Bailey, K. (2018). Reimagining alienation within a relational framework: evidence from the public sector in Ireland and the UK. The International Journal of Human Resource Management, 1-22.

Çavuş, M. F. (2006). İşletmelerde Personel Güçlendirme Uygulamalarının Örgütsel Yaratıcılık ve Yenilikçiliğe Etkileri Üzerine İmalat Sanayiinde Bir Uygulama. Basılmamış Doktora Tezi, SÜ Sosyal Bilimler Enstitüsü, Konya.

Çelik, M., \& Turunç, Ö. (2011). Duygusal Emek ve Psikolojik Sıkıntı: İş-Aile Çatışmasının Aracılık Etkisi. İstanbul Üniversitesi İşletme Fakültesi Dergisi, 40 (2), 226-250.

De Jong, J. P. J., \& Kemp, R. (2003). Determinants of Coworkers' Innovative Behaviour: An Investigation Into Knowledge Intensive Services. International Journal of Innovation Management, 7, 189-212.

Demerouti, E., Bakker, A. B., Nachreiner, F., \& Schaufeli, W. B. (2001). The Job Demands-Resources Model of Burnout. Journal of Applied psychology, 86(3), 499.

De Ruyter, K., Wetzels, M., \& Kleijnen, M., (2001). Customer Adoption of E-Services: An Experimental Study. International Journal of Service Industry Management 12 (2), 184-207.

Eren, E. (2007). Örgütsel Davranış ve Yönetim Psikolojisi. İstanbul, Beta Basım Yayın, İstanbul.

Fisher, R.T. (2001). Role stress, the type a behaviour pattern, and external auditor job satisfaction and performance. Behavioral Research in Accounting, 13, 143.

Folger, R., \& Cropanzano, R. (1998). Organizational Justice and Human Resource Management. Thousand Oaks, CA: Sage.

Folger, R., \& Konovsky. M. A. (1989). Effects of Procedural and Distributive Justice on Reactions to Pay Raise Decisions. Academy of Management Journal, 32, 115-130.

Fornell, C., \& Larcker, D. F. (1981). Structural equation models with unobservable variables and measurement error: Algebra and statistics. Journal of Marketing Research, 17, 382-388.

Fromm, E. (1955). The Sane society. New York: Rinehart

Gökçe, O. \& Şahin, A. (2003). Yönetimde rol kavramı ve yönetsel roller. Sosyal ve Ekonomik Araştırmalar Dergisi, 3(6),133-156.

Gökçe, G., Şahin, A., \& Bulduklu, Y. (2010). Herzberg' in Çift Faktör Kuramı ve Alt Gelir Gruplarında Bir Uygulama: Meram Tip Fakültesi Örneği. Sosyal Ekonomik Araştırmalar Dergisi, 10(20), 233-246. 
Greenberg, J., \& R. A. Baron. (2000). Behavior in Organizations (Seventh Edition). New Jersey: Prentice Hall.

Gullahorn, J. T. (1956). Measuring Role Conflict. American Journal of Sociology, 61(4), 299-303.

Gümüşlüoğlu, L., \& Ilsev, A. (2009). Transformational Leadership, Creativity and Organizational İnnovation. Journal of Business Research, 62, 461-473.

Hair, J.F., Tomas, G., Hult, M., Ringle, C.M. \& Sarstedt, M. (2014). A Primer on Partial Least Square Structural Equations Modeling (PLS-SEM), Los Angeles: Sage.

Hegel, G. W. F. (1910). The Phenomenology of Mind (trans. Baillie, J.). Swan Sonnonschein.

Henseler, J., Ringle, C. M., \& Sarstedt, M. (2015). A New Criterion For Assessing Discriminant Validity in Variance-Based Structural Equation Modeling. Journal of the Academy of Marketing Science, 43(1), $115-135$.

Howard, L. W., \& Cordes, C. L. (2010). Flight From Unfairness: Effects of Perceived Injustice on Emotional Exhaustion and Employee Withdrawal. Journal of Business and Psychology, 25(3), pp.409428.

Hull, F. M., Friedman, N. S., \& Rogers, T. F. (1982). The Effect of Technology on Alienation from Work: Testing Blauner's Inverted U-Curve Hypothesis for 110 Industrial Organizations and 245 Retrained Printers. Work and Occupations, 9(1), 31-57.

İmamoğlu, Z., \& Soybilgen, B. (2014). Politika Notu: Türkiye'de Bilgi Teknolojisi Ve Ekonomi. https://betam.bahcesehir.edu.tr/wp-content/uploads/2015/06/PolitikaNotu004.pdf

Jawahar, I. M., Stone, T. H., \& Kisamore, J. L. (2007). Role Conflict and Burnout: The Direct and Moderating Effects of Political Skill and Perceived Organizational Support on Burnout Dimensions. International Journal of Stress Management, 14(2), 128-142.

Kanungo, R. N. (1992). Alienation and Empowerment: Some Ethical Imperatives in Business. Journal of Business Ethics, 11(5-6), 413-422.

Kanungo, R.N. (1982b). Work Alienation: An Integrative Approach. New York: Praeger.

Kaya, U., \& Serçeoğlu, N. (2013). Duygu İşçilerinde İşe Yabancılaşma: Hizmet Sektöründe Bir Araştırma, Çalışma ve Toplum, 36(1).

Kim, W. C., \& Maubourge, R. (1997). Value Innovation. Havard Business Review, 1.

Khan, M. A. S., Du Jianguo, A. M., Saleem, S., Boamah, K. B., Javed, U., \& Usman, M. (2019). Rejuvenating The Concept Of Work Alienation Through Job Demands-Resources Model And Examining Its Relationship With Emotional Exhaustion And Explorative And Exploitative Learning. Psychology Research and Behavior Management, 12, 931.

Korman, A. K., Wittig-Berman, U., \& Lang, D. (1981). Career Success and Personal Failure: Alienation in Professionals and Managers. Academy of Management Journal, 24(2), 342-360.

Kuru, F. K. (2009). Küresel Mali Kriz Kapsamında İnsan Kaynakları Yönetimi Uygulamaları ve Örgütsel Yabancılaşma Arasındaki İlişkinin İncelenmesine Yönelik Bir Araştırma. Yayınlanmamış Yüksek Lisans Tezi, Yıldız Teknik Üniversitesi Sosyal Bilimler Enstitüsü, İstanbul.

Lim, S. (2008). Job Satisfaction Of İnformation Technology Workers in Academic Libraries. Library \& Information Science Research, 30(2), 115-121. 
Marx, K. (1844/1975). Excerpts from James Mill's Elements of Political Economy. In R. Livingstone \& G. Benton (Trans.). Karl Marx: Early writings (pp. 259-278). London: Penguin.

Merkhe, J. S. S. (2015). The Impact of Perception of Organizational Injustice on Work Alienation. Doctoral Dissertation, The Middle East University

Michaels, R. E., Dubinsky, A. J., Kotabe, M., \& Un Lim, C. (1996). The Effects of Organizational Formalization on Organizational Commitment and Work Alienation in US, Japanese and Korean industrial salesforces. European Journal of Marketing, 30(7), 8-24.

Moon, H., Kamdar, D., Mayer, D. M., \& Takeuchi, R. (2008). Me or We? The Role of Personality and Justice as Other-Centered Antecedents to Innovative Citizenship Behaviors Within Organizations. Journal of Applied Psychology, 93(1), 84.

Mottaz, C. (1981). Some Determinants of Work Alienation The Sociological Quarterly 22, 515-529.

Organ, D. W., \& Greene, C. N. (1981). The Effects of Formalization on Professional Involvement: A Compensatory Process Approach. Administrative Science Quarterly, 237-252.

Öcal, H., \& Barın, N. (2016). Örgütlerde Otantik Liderlik Davranışının İşe Yabancılaşma İle İlişkisi: Bursa İli Dericilik Sektöründe Bir Araştırma. Is, Guc: The Journal of Industrial Relations \& Human Resources, 18(2).

Özbek, M. F., \& Umarov, A. (2010). Prosedürel Adalet, Dağıtımsal Adalet ve Değersel Bağlllık İlişkisi: Bir Yapısal Eşitlik Modeli Uygulaması. Atatürk Üniversitesi İktisadi ve İdari Bilimler Dergisi, 24(2), 307-318.

Özkan, M. R. (2016). Bilgi teknolojileri sektöründe Nitelikli İşgücü Problemi ve İşkur'un Rolü, Çalışma ve Sosyal Güvenlik Bakanlığı Türkiye İş Kurumu Genel Müdürlüğü, (Uzmanlık Tezi) Ankara.

Özkoç, A. G. (2016). Job Autonomy and Work Alienation: Organizational and Occupational Identification as a Mediator. European Journal of Business and Management 8 (11), 61-73.

Ramaswami, S. N., Agarwal, S., \& Bhargava, M. (1993). Work Alienation of Marketing Employees: Influence of Task, supervisory and Organizational Structure Factors. Journal of the Academy of Marketing Science, 21(3), 179-193.

Ringle, C, M., Wende, S., \& Becker, J.-M. (2015). SmartPLS 3. www.smartpls.com

Rizzo, J. R., House, R. J., \& Lirtzman, S. I. (1970). Role Conflict and Ambiguity in Complex Organizations. Administrative science quarterly, 150-163.

Rothmann, S., \& Jordaan, G. M. E. (2006). Job Demands, Job Resources and Work Engagement of Academic Staff in South African Higher Education Institutions. SA Journal of Industrial Psychology, 32(4), 85102.

Sayü, P. (2014). The Relationship Between Organizational Justice And Work Alienation. Unpublished Master Dissertation, Marmara University, İstanbul

Seeman, M. (1959). On Personal Consequences of Alienation in Work. American Sociological Review, 31,98 .

Shantz, A., Alfes, K., Bailey, C., \& Soane, E. (2015). Drivers and Outcomes of Work Alienation: Reviving a Concept. Journal of Management Inquiry, 24(4), 382-393. 
Shantz, A., Alfes, K., \& Truss, C. (2014). Alienation From Work: Marxist Ideologies and Twenty-FirstCentury Practice. The International Journal of Human Resource Management, 25(18), 2529-2550.

Shepard, J.M. (1971). Automation and Alienation, A Study of Office and Factory Workers, The MIT Press, 25.

Sookoo, N. (2014). Perceptions of Injustice and Alienation Dynamics Within the Workplace. Journal of the Department of Behavioural Sciences, 3(1).

St-Pierre I, H. D. (2010). The Relationship Between Organizational Justice and Workplace Aggression". Journal of Advanced Nursing, 66(5), 1169-1182.

Taştan, S. B. (2014). The Theoretıcal Implications of Job Demands--Resources Model: A Research Study On The Relations of Job Demands, Supervisor Support And Job Autonomy With Work Engagement. Ataturk University Journal of Economics \& Administrative Sciences, 28(4).

Tekeli, M., \& Buyruk, L. (2016). Konaklama İşletmelerinde Algılanan Örgütsel Adaletin İşe Yabancılaşma Üzerine Etkisi: Kapadokya Örneği, (Master's thesis, Nevşehir Hacı Bektaş Veli Üniversitesi).

Thibaut, J., \& Walker, L. (1978). A Theory of Procedure. California Law Review, 66, 541-566.

Thibaut, J. W., \& Walker, L. (1975). Procedural Just Ice: A Psychological Analysis. Hillsdale, NJ: Lawrence Erlbaum

Tokgöz, F. (2019). Rol Çatışması ve Rol Belirsizliğinin Örgütsel Yabancılaşmaya Etkisi: Kastamonu İli Kamu Kurumlarında Bir Uygulama, (Doctoral Dissertation, Kastamonu Üniversitesi).

Tolay, E., Sürgevil, O., \& Topoyan, M. (2012). Akademik Çalışma Ortamında Yapısal ve Psikolojik Güçlendirmenin Duygusal Bağllılı ve İş Doyumu Üzerindeki Etkileri. Ege Akademik Bakış, 12(4), $449-465$.

Turgut, T. (2011). Çalışmaya Tutkunluk: İş yükü, Esnek Çalışma Saatleri, Yönetici Desteği ve İş-Aile Çatışması ile İlişkileri. Atatürk Üniversitesi İktisadi ve İdari Bilimler Dergisi/Journal of Economics and Administrative Sciences, 25(3-4),155-179.

Turgut, T., \& Kalafatoğlu, A. G. Y. (2016). İşe Yabancilaşma ve Örgütsel Adalet. ISGUC The Journal of Industrial Relations and Human Resources, 18(1), 23-46.

TÜBISSAD (2019). Bilgi ve İletişim Teknolojileri Sektörü 2018 Pazar Verileri http://www.tubisad.org.tr/tr/images/pdf/tubisad290419.pdf (Erișim Tarihi: 29.01.2020).

Tükel, İ. (2012). Modern Örgütlerde Yabancılaşma ve Kafka'nın Dönüşüm Romanının Bu Bağlamda Analizi, Dokuz Eylül Üniversitesi Edebiyat Fakültesi Dergisi, 1(2), 34-50.

Tyler, T. R., \& Lind, E. A. (2002). Procedural Justice. In Handbook of Justice Research in Law, 65-92. Springer, Boston, MA.

Yüce-Selvi, Ü., \& Sümer, N. (2018). İş Güvencesizliğinin Etkileri: Temel Yaklaşımlar ve Olumsuz Etkileri Düzenleyici Faktörler Üzerine Bir Derleme. İş ve İnsan Dergisi, 5(1), 1-17.

Yürür, Ş., \& Demir, A. G. K. (2011). Örgütsel Adalet Ve Psikolojik Güçlendirme: Karş1lıklı Etkileri Üzerine Bir Araştırma. Süleyman Demirel Üniversitesi İktisadi ve İdari Bilimler Fakültesi Dergisi, 16(3), 311-335.

Zengin, Y., \& Kaygın, E. (2016). Mobbing'in Örgütsel Yabancılaşmaya Etkisi: Bankacılık Sektörü Üzerinde Bir Araştırma. Proceedings E-Book II, 55. 